\title{
TRANSIENT INDUSTRY EFFECTS: HOW MUCH ARE INDUSTRIES EXPOSED?
}

\author{
Melina Moleskis \\ Miguel A. Ariño \\ Miguel Canela
}




\title{
TRANSIENT INDUSTRY EFFECTS: HOW MUCH ARE INDUSTRIES EXPOSED?
}

\author{
Melina Moleskis \\ Miguel A. Ariño ${ }^{2}$ \\ Miguel Canela ${ }^{3}$
}

\begin{abstract}
An important factor contributing to performance heterogeneity is transient industry effects. In this paper, we explore the importance of such effects in the cava, beer and automotive sectors using the methodology of Ariño et al. (2008). We assess the exposure of these industries to the business cycle and measure the intensity of their responsiveness. Further, the scope of our analysis includes key social and political events that may help managerial decision making. Our study draws on consumer attitudes and changing habits, as well as the effectiveness of government intervention schemes. This paper contributes to the transient industry literature by providing new insights on the importance of transient effects. The application of the transient industry effects model allows us to identify lasting changes in the relationship of an industry with the business cycle, as well as important external shocks whose impact cannot be neglected in strategic planning and decision making by managers and policy makers.
\end{abstract}

Keywords: transient industry effects; business cycle; cava; beer; automotive

\footnotetext{
${ }^{1}$ Phd Candidate, IESE. E-mail: MMoleskis@iese.edu.

${ }^{2}$ Professor, Managerial Decision Sciences and Analysis of Business Problems, IESE. E-mail: MAArino@iese.edu.

${ }^{3}$ Professor, Managerial Decision Sciences, IESE. E-mail: MCanela@iese.edu.
} 


\section{TRANSIENT INDUSTRY EFFECTS: HOW MUCH ARE INDUSTRIES EXPOSED?}

\section{Introduction}

A central empirical question for strategic management has been the relative role of industry, corporate parent and business unit effects on firm performance. In the quest to decipher the dynamics shaping firm performance, scholars have looked at the macroeconomic environment as one of the key factors affecting firm performance both directly and indirectly, through its interaction with industry effects (Schmalensee, 1985; Rumelt, 1991; Roquebert et al., 1996; McGahan and Porter, 1997; Hawawini et al., 2003). Having established the importance of industry effects through empirical findings, recent literature has attempted to measure the magnitude of such effects across industry settings (Ariño et al., 2008).

In their 2008 paper “A Model to Evaluate Transient Industry Effects," Ariño et al. (2008) introduce a method to measure the impact of the business cycle on the level of activity in an industry. The authors conceptualize this impact in terms of the exposure and intensity of exposure and apply their method to the Spanish cava and beer industries, as well as the international automotive sector, for data ranging from 1985 to 1998 . This paper serves as a follow-up to the 2008 paper. By adopting the same identification strategy, operationalization of variables and choice of industries, we seek to replicate the significant results unveiled in the 2008 paper while incorporating the latest data.

We set out to test the applicability of the method of Ariño et al. (2008) on the movements of the business cycle to date, including the latest economic crisis. In addition, we extend the scope vertically to other countries and compare our results. We find that the strong exposures continue to exist, in spite of the changing landscape in consumer preferences and exogenous shocks that have impacted consumption habits. We also draw some interesting comparisons between industries and countries, which may help shape business strategy and public policy. This paper contributes to the transient industry literature by providing new insights on the importance of transient effects. The application of the transient industry effects model allows us to identify lasting changes in the relationship of an industry with the business cycle, as well as important external shocks whose impact cannot be neglected in strategic planning and decision making by managers and policy makers.

We proceed by applying the model to: (a) the Spanish cava industry for the period 1985 to 2013, (b) the beer industry in Spain, the United Kingdom, Germany, France, Italy and the United States, and (c) the automotive sector in Spain, the United Kingdom, Germany, France, Italy, the United States and Japan for the period 1985 to 2013. We simultaneously present and discuss our findings at the industry level. 


\section{Theoretical Framework}

Industry effects have long been considered in the strategic management literature as important factors affecting business performance. Industry effects can be stable or transient. Stable industry effects reflect the influence of industries' structural characteristics on the performance of firms, such as barriers to entry and concentration, while the transient component of industry effects measures the sensitivity of profitability to the impact of business cycles on the industry.

Classical industrial organization theory explains firm performance in terms of the structureconduct-performance paradigm, which says that exogenous industry effects, such as barriers to entry and concentration (Schmalensee, 1985; Rumelt, 1991), are the dominant influences on performance. Beyond industry effects, year, corporate parent and business unit effects have been considered in the strategic management literature as important factors affecting performance. Over the years, various scholars have assessed the relative importance of these factors for their impact on performance by decomposing the variance in profitability across business segments into components associated with year, industry, the corporate parent and business-specific effects. This approach to estimating the importance of each of the organizational factors based on the amount of variance explained seeks to document relationships and their relative importance without stipulating causality (McGahan and Porter, 2002).

Schmalensee (1985) first highlights the important role of the industry in its relationship with performance when he reports a 19.6\% contribution of industry effects to the observed variance in business unit accounting returns. His seminal results feature the importance of industry effects and have inspired scholars from the strategic management field to investigate this phenomenon further. Notably, Rumelt (1991) improves upon the cross-sectional methods of Schmalensee (1985) by employing a four-year period of study, from 1974 to 1977. Rumelt (1991) reports that stable industry effects account for only about $8 \%$ of variance but, importantly, he distinguishes between stable industry effects and annual fluctuations or transient effects. In fact, the sum of the stable and transient industry effects of Rumelt (1991) is comparable to the composite industry effect in Schmalensee (1985). To be exact, Rumelt (1991) finds that industry effects account for 16\% of the variance in business unit profitability of U.S. manufacturing firms from 1974 to 1977, and that only half of this variance is due to stable industry effects, with $49 \%$ to $57 \%$ of the variance attributed to transient effects. His results support the contention that transient industry effects are more important than stable industry effects in explaining performance heterogeneity.

Moreover, McGahan and Porter (1997) use data from 1981 to 1994 on U.S. public corporations and expand the analysis beyond manufacturing to include all sectors of the economy, except government and finance. Their results indicate that industry effects account for 7\% to 19\% of variance, with strong differences in the importance of effects by sector. For example, in manufacturing, the influence of industry effects is lower than in any other sector during the period covered. Further, in a later paper, the authors point out that the Standard Industrial Classification (SIC) system used in many studies to classify industries at the four-digit level tends to include excessively broad industry definitions and, as a result, the importance of industry is likely to be understated (McGahan and Porter, 2002).

Thereafter, studies have delved deeper into the importance of transient industry effects. Notably, Hawawini et al. (2003) adopt value creation as opposed to accounting measures and find that transient industry effects explain between $6 \%$ and $15 \%$ of variance in performance, and this level depends on whether industry outliers (overperformers and underperformers) are included or excluded. More specifically, after removing the top and bottom two performers from each

2 - IESE Business School-University of Navarra 
industry, the authors conclude that "industry structure matters only for firms that do not manage to be the leader or the loser, i.e., for firms with average managerial capabilities and performance" (Hawawini et al., 2003). Thus, for the firms that form the bulk of the industry, transient effects are important factors for their performance.

In spite of the importance of transient industry effects for the average firm and the variance in their magnitude from sector to sector, until recently, no method existed for evaluating their effect. Acknowledging this gap, Ariño et al. (2008) devise a method to measure such effects for any particular industry. In particular, the authors develop a model to measure annual fluctuations in industry sales based on annual variations of the economic cycle, and use ordinary least-squares (OLS) regression to capture transient industry effects. The authors differentiate their work by turning readers' attention to the industry as the level of analysis, in lieu of the firm. Using this method across various industries, they find notable correlations between the independent and dependent variables. The model is inspired by the capital asset pricing model, which is well known in finance.

\section{Research Methodology}

\section{Model Specification}

The model developed by Ariño et al. (2008) is similar to the capital asset pricing model (CAPM), a tool financial investors use to allocate their investments and which considers both the expected return and the level of risk associated with a particular investment (Merton, 1973; French, 2003). The expected return indicates the average profitability over a given period while the standard deviation measures the risk, or volatility, of the investment over the same period. Total risk can be decomposed into systemic and nonsystemic risk. Systemic risk, also known as market risk, captures the responsiveness of the investment to changing market conditions and differs for each investment. In the CAPM model, systemic risk is captured by the beta and can be estimated as the slope coefficient in a linear regression of past returns of the investment on those of the general index, which represents the market. For instance, for an investment with $\beta=1$, a 5\% variation in the market return results in a 5\% variation in the expected return of the investment, on average. Nonsystemic, or idiosyncratic, risk is the risk stemming from the particular characteristics of the investment, and it can be eliminated through diversification. Nonsystemic risk is derived from the error term in the regression. Thus, the CAPM model can be expressed using the following equation:

$$
\text { Expected Return }(\mathrm{t})=\text { Constant }+\beta{ }^{*} \text { Market Return }(\mathrm{t})+\text { Error }(\mathrm{t})
$$

In evaluating transient industry effects and their effect on industry performance, the model can be rewritten as follows:

$$
\text { Industry Performance }(t)=\text { Constant }+\beta{ }^{*} \text { Economy }(t)+\text { Error }(t)
$$

Ariño et al. (2008) define the exposure of an industry to the economy as the extent to which periodic industry fluctuations in performance can be explained by the economic cycle. From the simple linear regression equation above, exposure is captured by the magnitude of R-squared $\left(R^{2}\right)$, which represents the proportion of the variance explained by the regression equation. In practice, $\mathrm{R}$-squared is calculated as the variance of the predicted values divided by the variance of the actual values. In other words, the larger the error term is, the lower the R-squared will be and consequently the lower the exposure of the industry to the economy. R-squared thus represents the proportion of systemic risk to total risk. Further, the authors define the intensity 
of exposure as being the impact of a percentage point of change in the general economic activity on the industry activity. Thus, the intensity of exposure corresponds to the systemic or market risk as per the CAPM model, and is captured by the estimated slope coefficient denoted as beta $(\beta)$. The higher the beta is, the greater the responsiveness of the industry activity to changing market conditions. The intensity of exposure differs for each industry.

In operationalizing the dependent variable, Ariño et al. (2008) employ the level of industry activity as captured by annual sales, rather than profitability. This preference is justified by the fact that profit performance is related to both revenues as well as to costs and, as a result, profitability is a function of many variables that have an effect on costs, at both the industry and firm levels. Using profitability as a dependent variable would thus allow for firm-specific effects to distort the results. However, sales are associated solely with industry revenues and not costs. Hence, to alleviate this concern, the authors use sales as a performance measure, which mitigates the need to control for intra-industry and firm-specific factors, thereby increasing the accuracy of the findings. Further, the authors employ the growth rate of gross domestic product (GDP) for each country as an indicator for the economic cycle. The preferred unit of measurement is the quantity of products sold instead of monetary sales, which has the advantage of filtering out the effect of inflation. Also, the authors use annual data in order to filter out seasonality. The time frame of the analysis dates back to the maturity of the industry, which varies according to both industry and country setting. Such a precaution is prudent in order to avoid heterogeneity in the sample stemming from the industry growth phase. Taking these operationalizations into account, the transient industry effects model can thus be expressed as follows:

$$
\text { Industry Sales }(t)=\text { Constant }+\beta{ }^{*} \text { GDP }(t)+\text { Error }(t)
$$

\section{Findings and Discussion}

\section{A. The Spanish Cava Industry}

Cava is a sparkling wine of denominated origin status, most of which is produced in Catalonia, Spain. Cava is produced in the same way as champagne in France but from different grape varieties, the most popular being Macabeu, Parellada and Xarello. About 95\% of all cava is produced in the Penedès area of Catalonia, and the two major producers are Codorníu and Freixenet.

Cava production is measured by the number of $75 \mathrm{cl}$ bottles produced, as obtained from statistical publications of the Cava Regulatory Board. From 1974 to 1985, cava production for the domestic market grew by around 55\%, from approximately 53 million to 83 million bottles. This stage of fast growth is evident in the evolution of the domestic cava market as depicted in Figure A1, where the data after 1998 is an update of the Ariño et al. (2008) paper. As we can see from the graph, after 1985, average industry growth decelerates and the industry seems to enter its maturity phase. As an industry approaches maturity, industry sales stop growing at high rates and the sales curve becomes noticeably flatter. This observation is important as it facilitates separation between the growth and maturity phases of an industry. Figure A2 depicts the evolutions of the cava industry and GDP in Spain. The cava industry grows much more steeply than GDP up to the mid-1980s, which is characteristic of industry growth. In addition, we note the increase in variance between consecutive years from 2004 onwards. 


\section{Figure A1}

Spanish cava, 1974-2013

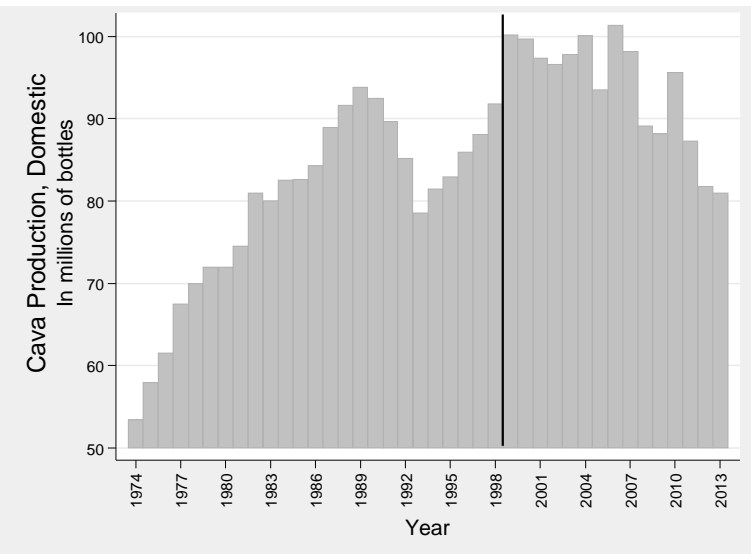

Figure A2

Cava market and GDP, Spain

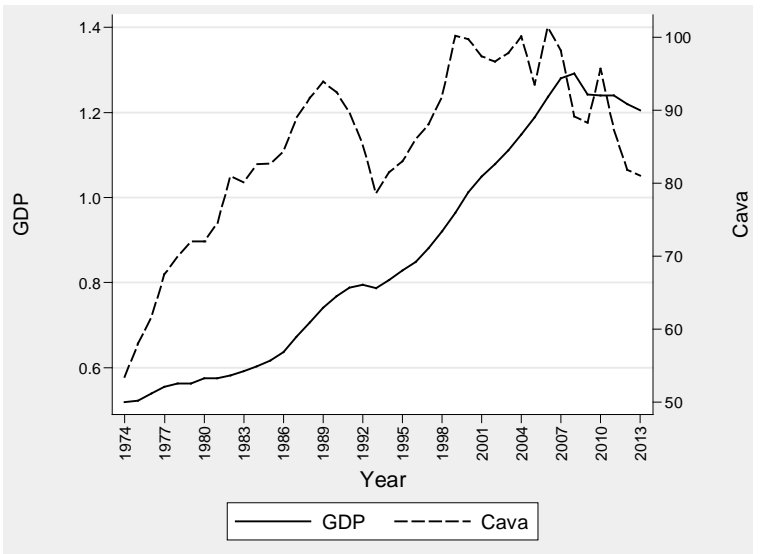

Source: Own elaboration based on Consejo Regulador del Cava, "Cava Shipments in 2013" and "Cava shipments in 2010, http://www.crcava.es/english/bodegas.htm, last access July 2015 and on Organisation for Economic Co-operation and Development (OECD), Statistics section, http://stats.oecd.org/, last access, July 2015.

To provide support for our observations regarding the onset of maturity in the Spanish cava industry, we perform a sensitivity analysis by varying the starting year for our study as well as the independent variables considered. In particular, we examine the effects of (1) year, (2) GDP rate, and (3) both year and GDP rate, on the rate of change of cava production for various time periods. By varying our choice of independent variables, we are able to determine that including the year as an explanatory variable adds very little to our model in terms of the explanatory power of our results (i.e., R-squared). Thus, we choose not to include the year. Further, by varying our choice of the first year of our analysis (from 1983 to 1987), we are able to show that the significance of the coefficients and the fit of our model do not change much. Hence, the choice of starting year is not critical to our analysis. The results of this sensitivity analysis are shown in Table A1.

\section{Table A1}

Sensitivity analysis: Regression output for different starting years

\begin{tabular}{|c|c|c|c|c|c|c|c|c|c|}
\hline \multicolumn{10}{|c|}{ Independent variables } \\
\hline \multirow[b]{2}{*}{ Starting year } & \multirow[b]{2}{*}{ Coeff. } & \multirow{2}{*}{$\begin{array}{l}\text { Year } \\
\text { t-stat }\end{array}$} & \multirow[b]{2}{*}{$\mathbf{R}^{2} \%$} & \multirow[b]{2}{*}{ Coeff. } & \multicolumn{2}{|c|}{ GDP \% } & \multicolumn{3}{|c|}{ Year and GDP \% } \\
\hline & & & & & t-stat & $\mathbf{R}^{2} \%$ & Coeff. & t-stat & $\mathbf{R}^{2} \%$ \\
\hline 1983 & -0.122 & -1.26 & 5.2 & 0.975 & 2.73 & 20.4 & 0.939 & 2.32 & 20.5 \\
\hline 1984 & -0.143 & -1.40 & 6.5 & 0.973 & 2.67 & 20.3 & 0.919 & 2.18 & 20.5 \\
\hline 1985 & -0.136 & -1.24 & 5.4 & 0.989 & 2.69 & 21.2 & 0.998 & 2.28 & 21.2 \\
\hline 1986 & -0.151 & -1.29 & 6.0 & 0.989 & 2.64 & 21.2 & 1.00 & 2.19 & 21.2 \\
\hline 1987 & -0.151 & -1.20 & 5.5 & 0.982 & 2.57 & 20.9 & 1.02 & 2.17 & 21.0 \\
\hline
\end{tabular}

Source: Own elaboration based on Consejo Regulador del Cava, "Cava Shipments in 2013" and "Cava shipments in 2010, http://www.crcava.es/english/bodegas.htm, last access July 2015 and on Organisation for Economic Co-operation and Development (OECD), Statistics section, http://stats.oecd.org/, last access, July 2015. 
Following Ariño et al. (2008), we argue that, because cava production can be adjusted to meet demand and stocks of cava bottles are generally low (cava usually ages between 12 months and three years), cava demand tends to meet supply and therefore production is a good indicator of consumption. Further, we compute the rate of change in annual production, which facilitates the interpretation of our results. Thus, the operationalization for the level of activity of the domestic cava industry is the annual rate of change in the number of $75 \mathrm{cl}$ bottles produced for the Spanish market.

The business cycle is captured by the growth rate of gross domestic product (GDP), in volumes. In the period 1985 to 2013, the average growth rate of Spanish GDP was $2.44 \%$ and that of cava was $0.05 \%$. Taking the stage of the business cycle into account allows us to be more specific about the current growth rate in the industry's activity (Ariño et al., 2008). Whereas the Spanish domestic cava market grew at an average rate of 0.05\% from 1985 to 2013, there were significant fluctuations around this level, which can be attributed to a number of different causes. In our analysis we are interested in the contribution of the business cycle to the total observed variance.

Figure A3 juxtaposes the evolution of growth rates in the cava industry and Spanish GDP. Like before, we can see more clearly the increase in variation in cava production during the years from 2005 to 2013. Ariño et al. (2008) find a strong relationship between the cava rate and the GDP rate; the business cycle accounts for $63 \%$ of fluctuations in the activity of the cava industry for the years 1985 to 1998 - i.e., the exposure of the cava industry to the business cycle is 63\%. With the inclusion of recent data up to 2013, exposure falls to $21 \%$. This can be attributed to the pronounced effects of the recent economic crisis on cava production. The increasing variation in the cava rate has had a weakening effect on exposure following 2005 (1.2\%).

\section{Figure A3}

Evolution of growth rates in Spanish GDP and cava production, 1985-2013

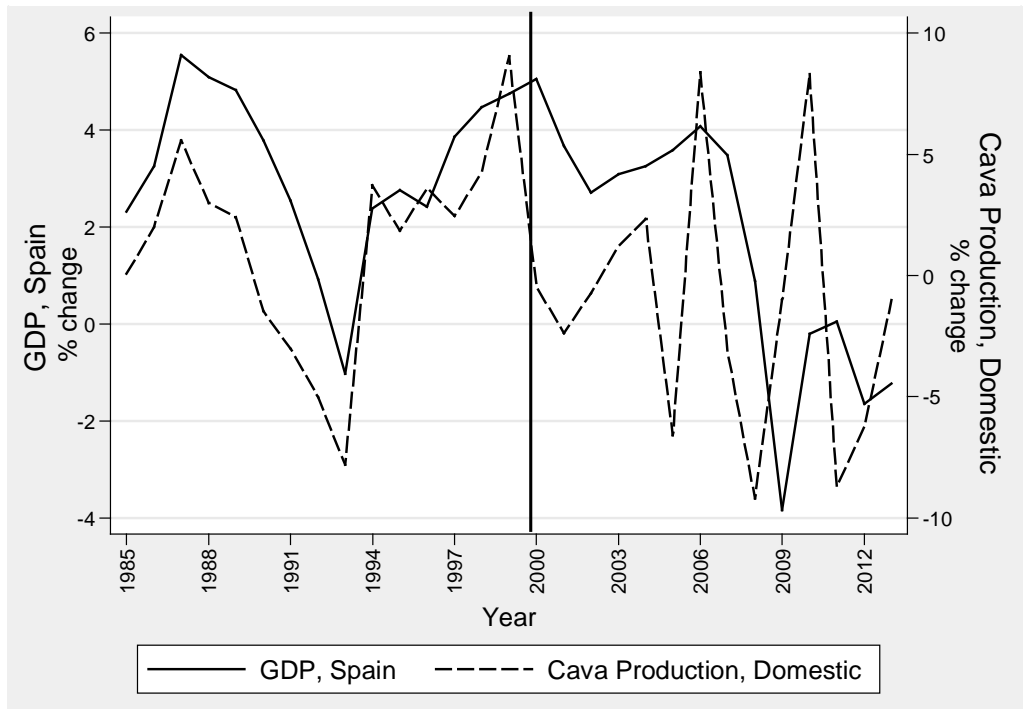

Source: Own elaboration based on Consejo Regulador del Cava, "Cava Shipments in 2013" and "Cava shipments in 2010, http://www.crcava.es/english/bodegas.htm, last access July 2015 and on Organisation for Economic Co-operation and Development (OECD), Statistics section, http://stats.oecd.org/, last access, July 2015. 
Figure A4 depicts these abrupt changes in cava production as influential points - i.e., observations that substantially change the estimate of the regression coefficients because of their leverage and outlierness. Using Cook's distance ${ }^{1}$ (Cook's D) as a measure of influence (Hamilton, 2004), and the rule of thumb whereby observations whose Cook value is greater than $4 / \mathrm{N}$ (in this case, $4 / 29=0.138$ ) can be of concern, we identify Year $2009(D=0.398)$ and Year $2010(D=0.284)$ as influential points.

\section{Figure A4}

Identification of 2009 and 2010 as influential points

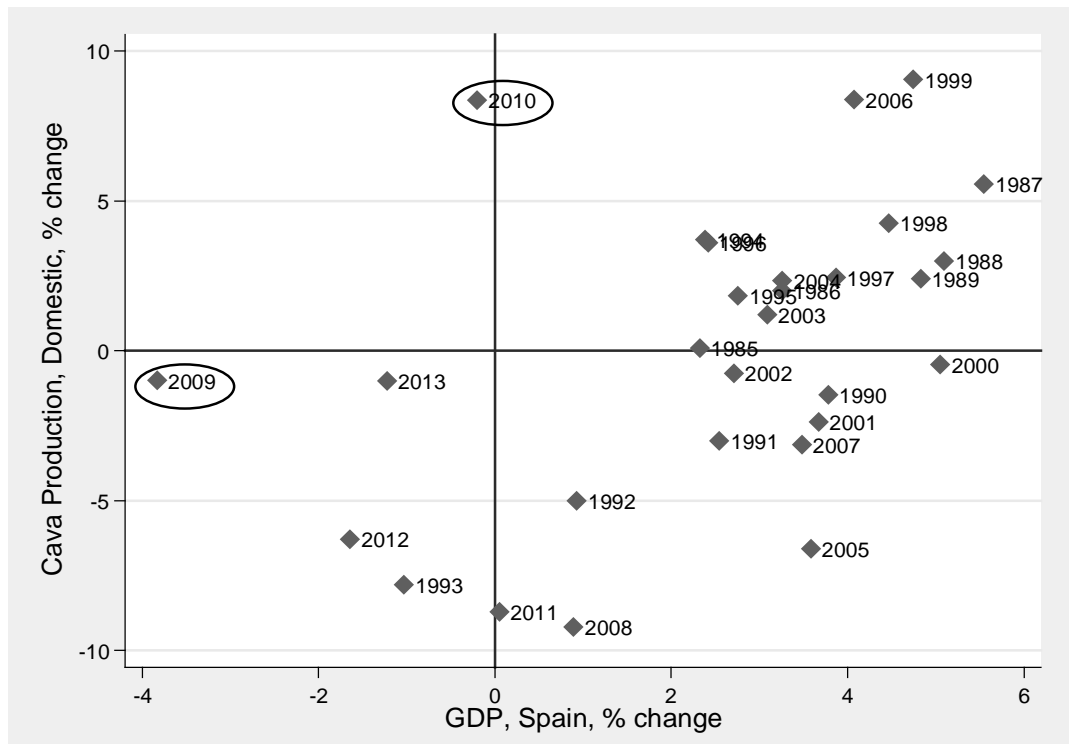

Source: Own elaboration based on Consejo Regulador del Cava, "Cava Shipments in 2013" and "Cava shipments in 2010, http://www.crcava.es/english/bodegas.htm, last access July 2015 and on Organisation for Economic Co-operation and Development (OECD), Statistics section, http://stats.oecd.org/, last access, July 2015.

So far, we have shown that the high correlation and comovement of GDP and cava production rates that were evident up until the onset of the 2008 economic crisis are not replicated in the period from 2008 to 2010. The current crisis has had an impact on the relationship between these two variables. We proceed to investigate the change in the relationship of GDP and cava rates over the period from 1985 to 2013. Since we have no evidence or theory for a lagged reaction, we allow for a synchronized reaction and account for the different shocks during our period of study. We identify each shock separately, based on public knowledge of historic events in Spain. In this way, we identify a list of shocks to the Spanish cava industry in the years 1999, 2005, and 2008 to 2010.

- Y2K (1999). The year 1999 marked the festivities for the turn of the century around the world. The year 2000, or Y2K, was duly welcomed with celebrations and accompanied by what appears to be an increased consumption of cava (a $9 \%$ increase compared with the

\footnotetext{
${ }^{1}$ Cook's distance measures the effect of deleting a given observation. Data points with large residuals (outliers) and/or high leverage may distort the outcome and accuracy of a regression. Points with a large Cook's distance are considered to merit closer examination in the analysis. It is calculated as follows:

$D_{i}=\left[\Sigma^{n_{j=1}}\left(Y_{j}-Y_{j(i)}\right)^{2}\right] /\left(p^{*} \mathrm{MSE}\right)$

$\mathrm{Y}_{\mathrm{j}}$ is the prediction from the full regression model for observation $j$;

$\mathrm{Y}_{\mathrm{j}(\mathrm{i})}$ is the prediction for observation $j$ from a refitted regression model in which observation $i$ is omitted;

$p$ is the number of fitted parameters in the model;

MSE is the mean square error of the regression model.
} 
previous year). This is not surprising since cava is the preferred drink for celebrations and festive occasions in Spain. In view of the occasion, cava producers responded accordingly with an increase in cava production of 9\%, which surpassed the 4.7\% rate of economic growth in 1999. As a result, the correlation between the business cycle and the cava industry is slightly distorted at this time juncture. Hence, in our analysis, we control for the year 1999 using a dummy variable to represent the shock.

- The 2005 boycott. Beyond social and economic factors, some key political developments affected the cava industry as well. Specifically, in 2005, a "New Statute of Autonomy for Catalonia" was drafted and approved by the Catalan parliament, as an amendment to the Statute of Autonomy of Catalonia of 1979. The new statute included articles designed to expand the authority of the Generalitat de Catalunya (Government of Catalonia). The proposal was submitted to and approved by the Spanish Congress of Deputies but sternly opposed by the main opposition party at the time (the Partido Popular, or Popular Party), the surrounding autonomous communities of Aragon, the Balearic Islands and the Valencian Community, as well as intellectuals and the majority of the Spanish media. The nationalist debate harbored feelings of resentment towards the region of Catalonia.

Catalonia is privileged in the production of cava because of the product's Denominación de Origen (D0, or Designation of Origin) status. In fact, 95\% of cava is produced in Catalonia, rendering it a source of both pride and risk for the northeastern region. The nationalist debate led to a boycott of Catalan products in 2005 and cava sales dropped 6.6\% compared with the previous year. This fall in cava consumption, in spite of an increase in GDP (3.6\%), could be attributed to the attempt of disgruntled Spaniards to boycott the Catalan economy. The boycott was short-lived, perhaps because of the long traditions of cava in Spain and the shortage of economical substitutes, which make demand fairly inelastic. In our analysis, we control for the boycott in 2005 using a dummy variable for that year.

- The 2008, 2009, and 2010 economic crisis. In 2008, there was a sharp drop in the production of cava of about 9\% whereas GDP growth fell to 0.9\%. The drop reflects the response of cava producers to the troubling deceleration in domestic GDP and the anticipated financial crisis spreading rapidly among developed economies through the cracks in the banking system. By the end of 2009, unemployment soared to $18.8 \%$ (37\% for young people) ${ }^{i}$ and GDP moved into negative territory $(-3.8 \%)$, whereas cava production dropped by only $1 \%$ as a correction to the overreaction of the previous year. In 2010, with the economy recovering from negative growth rates to stability (around 0\%), cava production and consumption expanded significantly, as producer and consumer confidence was repaired to a certain extent.

In our analysis, we perform linear regressions of the cava rate on the GDP rate over the period from 1985 to 2013. Since the nature of our data is a time series that raises concerns for heteroskedasticity and autocorrelation of standard errors, we also apply the Newey-West method for obtaining robust standard errors for the OLS estimates (Hamilton, 2004). The command "newey" in Stata produces Newey-West standard errors for coefficients estimated by OLS regression. The error structure is assumed to be heteroskedastic and autocorrelated up to a certain lag. By specifying the lag to be zero, the OLS estimates are the same and only the standard errors are adjusted.

The results are presented in Table A2. Without any adjustment for the aforementioned shocks, the exposure of the cava industry to the business cycle is at the low level of $21.2 \%$ and the intensity of exposure is 0.989 . When accounting for the Y2K celebrations by including a dummy 
variable for the year 1999, exposure improves to 28.2\%. Alternatively, controlling for the shock in 2005 generated by the boycott against Catalonian products by means of a dummy variable raises the exposure from $21.2 \%$ to $30.3 \%$. Further, by controlling for the shocks borne by the European debt crisis in the years 2008, 2009 and 2010, exposure rises to 55.4\%.

Finally, applying all the above adjustments together - i.e., using dummy variables for the years 1999, 2005, 2008, 2009 and 2010 - reveals an exposure of the Spanish cava industry to the economic cycle of $69.6 \%$, as given by R-squared. The intensity of the exposure, which measures the impact of a percentage point of change in the general economic activity on the industry activity, is given by the coefficient of GDP growth rate in percentage terms (1.47\%). This can be interpreted as follows: for each extra percentage point in the growth rate of Spanish GDP the cava production for the domestic market increases by $1.47 \%$ (hence, the intensity of this exposure is 1.47). This extra growth rate can be easily translated to absolute terms (number of bottles) and it means that, as the 2013 level of production is 81 million bottles, an extra percenatage point in the growth rate of Spanish GDP translates into an additional production of 1.19 million bottles of cava. All these findings are summarized in Table A2.

\section{Table A2}

OLS regressions of the rate of change in cava sales, Spain, 1985-2013

\begin{tabular}{|c|c|c|c|c|c|}
\hline Variable & $\begin{array}{c}\text { Model 1: } \\
\text { Benchmark }\end{array}$ & $\begin{array}{l}\text { Model 2: } \\
\text { Y2K }\end{array}$ & $\begin{array}{l}\text { Model 3: } \\
\text { Boycott }\end{array}$ & $\begin{array}{l}\text { Model 4: } \\
\text { Crisis }\end{array}$ & $\begin{array}{l}\text { Model 5: } \\
\text { All controls }\end{array}$ \\
\hline GDP growth rate & $\begin{array}{c}0.989^{\star *} \\
(2.47)\end{array}$ & $\begin{array}{c}0.878^{\star \star} \\
(2.23)\end{array}$ & $\begin{array}{c}1.050^{\star *} \\
(2.60)\end{array}$ & $\begin{array}{c}1.533^{\star \star \star} \\
(4.20)\end{array}$ & $\begin{array}{c}1.474^{\star \star \star} \\
(4.10)\end{array}$ \\
\hline Year 1999 & & $\begin{array}{c}7.227^{\star \star \star} \\
(7.43)\end{array}$ & & & $\begin{array}{c}6.051^{\star \star \star} \\
(6.48)\end{array}$ \\
\hline Year 2005 & & & $\begin{array}{c}-8.126^{\star \star \star} \\
(-10.70)\end{array}$ & & $\begin{array}{c}-7.881^{\star \star \star} \\
(-10.94)\end{array}$ \\
\hline Year 2008 & & & & $\begin{array}{c}-6.338^{\star * \star} \\
(-6.35)\end{array}$ & $\begin{array}{c}-6.523^{\star \star \star} \\
(-6.39)\end{array}$ \\
\hline Year 2009 & & & & $\begin{array}{c}9.127^{\star \star *} \\
(3.64)\end{array}$ & $\begin{array}{c}8.664^{\star * *} \\
(3.40)\end{array}$ \\
\hline Year 2010 & & & & $\begin{array}{c}12.915^{\star \star \star} \\
(9.94)\end{array}$ & $\begin{array}{c}12.666^{\star \star \star} \\
(9.46)\end{array}$ \\
\hline$R^{2}$ (exposure) & $21.15 \%$ & $28.17 \%$ & $30.28 \%$ & $55.43 \%$ & $69.63 \%$ \\
\hline Intensity (bottles) & 801,090 & 709,560 & 850,500 & $1,241,730$ & $1,193,940$ \\
\hline
\end{tabular}

${ }^{*} p<0.10 ;{ }^{* *} p<0.05 ;{ }^{* * *} p<0.01$

t-statistics in parenthesis (Newey-West method)

Source: Own elaboration based on Consejo Regulador del Cava, "Cava Shipments in 2013" and "Cava shipments in 2010, http://www.crcava.es/english/bodegas.htm, last access July 2015 and on Organisation for Economic Co-operation and Development (OECD), Statistics section, http://stats.oecd.org/, last access, July 2015.

\section{Discussion of the Spanish Cava Industry}

The application of the transient industry effects model allows us to identify important external shocks that affect the exposure and intensity of exposure of this industry, whose impact cannot be neglected either in the production planning and strategic decisions taken by the industry, or in the policy making assumed by the government. Refraining from causality claims, we provide evidence for the existence of a relationship between Spaniards enjoying cava and major festivities (Y2K), political developments (2005 boycott) or unusual economic circumstances (2008 recession). 
Overall, we find strong correlations between the cava industry's production and consumption and the business cycle, and our results closely resemble those of Ariño et al. (2008). Ariño et al. (2008) find that, for the period 1985 to 1998, roughly 63\% of the fluctuations in cava consumption are linked to the business cycle. We find that, for the period 1985 to 2013, the exposure of the cava industry to the economy remained at similarly high levels, with $69.6 \%$ of the fluctuations in consumption being related to the business cycle. In addition, the authors find that the intensity of this exposure is 1.73 in percentage terms or, in absolute terms, 1.57 million of bottles of cava (based on the 1998 level of production). By extending the time period up to 2013, we find that the intensity decreases to 1.47 in percentage terms (or, as per 2013 production levels, 1.19 million cava bottles).

\section{B. The Beer Industry}

Beer is the world's most widely consumed alcoholic beverage, and is the third most popular drink overall, after water and tea. Beer forms part of the culture of beer-drinking nations and is associated with social traditions such as annual beer festivals, as well as a rich pub culture. Beer is defined as the aggregation of lager, dark beer and stout. The fermentation process involved in making the beer determines the category. Within each category, pricing further segments the industry into premium, standard and economy groups. Imported beer is often more expensive than domestic beer. Further, beer sales are directed through two main channels: on-trade and offtrade. On-trade refers to beer sales through licensed restaurants, bars or pubs. Off-trade sales, a smaller proportion of overall sales, are facilitated through supermarkets or other vendors and consumed elsewhere, usually at home.

We examine the relationship between the consumption of beer per country and the fluctuations in GDP growth rate. Our choice of indicator for the level of industry activity is the number of hectoliters (hl) consumed domestically per year, following Ariño et al. (2008). Consumption statistics are available for beer, in the form of number of hectoliters consumed annually, which is the preferred indicator in statistical reports from the national beer associations from which our data have been obtained (Euromonitor, 2014).

For the analysis of the beer industry we look more closely at some European countries with varying beer traditions, in addition to the United States. We first analyze each country separately and then attempt to infer general conclusions from our results. Our time frame varies according to the availability of data. For Spain, we consider the period from 1987 to 2013. In the case of the United Kingdom, our data go back to 1980. For the rest of the countries, we consider the time period from 1999 to 2013, which is shorter but still insightful in that it encompasses several business cycles. In all cases, we ensure that our data span the maturity phase of the industry, and the choice of the starting year is scrutinized by considering different starting years in a sensitivity analysis.

We use simple linear regression to estimate the impact of the GDP growth rate on the annual rate of change in the number of hectoliters consumed domestically. We also apply the Newey-West method to calculate robust standard errors and t-statistics. We compute, as before, measures of exposure and intensity of exposure. We report these results for the benchmark model and the models with controls for exogenous shocks. Controls are in the form of dummy variables that capture the exogenous shock for that particular year. Our analysis considers volume (quantity) instead of value (price); quantities filter out the effect of inflation, category segmentation and distribution channels. 


\section{i. SPAIN}

Alcoholic beverages, including beer, play an important role as a source of nutrition and in the social and dietary habits of Spaniards since the pattern of mixing drinking with food, work and social habits is very common. Spain accounts for 9\% of the European beer market value, according to 2012 figures (Euromonitor, 2014). The Spanish beer market is characterized by high brand awareness and strong popularity among all types of Spanish consumers as well as strong distribution networks across the country. Beer is a very popular alcoholic beverage among all types of Spanish consumers and it tends to be preferred to wine or other alcoholic beverages as it is a moderately alcoholic drink that can be consumed before eating as an aperitif, as well as an accompaniment to meals.

The most popular beer category is lager, which comprises $86 \%$ of total volume sales, according to 2013 figures (Euromonitor, 2014). Within the lager category, standard lager accounted for the volume majority of lager sales (57\%) in Spain. Cruzcampo (Heineken España SA), Estrella Damm (Damm SA) and Mahou (Mahou SA) are the leading brands in standard lager. Domestic manufacturers account for around 50\% of total volume sales. Heineken España leads the beer market with a volume share of 32\% thanks to the popularity of its Spanish brand Cruzcampo. Mahou follows with a 30\% volume share, while Damm comes in third with a $13 \%$ volume share.

In order to analyze the impact of the business cycle on the Spanish beer industry, we use the consumption of beer in Spain measured as the total number of hectoliters of beer consumed. We consider yearly data from 1987 to 2013 . The maturity of the beer industry is already present in our time range and our choice of 1987 as the starting year is dependent on the availability of data. In order to make sure this arbitrary starting year does not affect our results, we inspect the output of various regression analyses, each considering different starting years around 1987, and verify that the estimates are similar. Figure B1 tracks the evolution of beer consumption in Spain over our period of study. As in the case of cava, we notice beer sales peaking in the year 2007, prior to the onset of the crisis. Figure B2 contrasts the growth rate of the consumption of beer in Spain and the growth rate of GDP, and shows that the two rates move very much in sync.

\section{Figure B1}

Beer consumption, Spain

\section{Figure B2}

$$
\text { Spain, \% GDP and \% beer consumption }
$$
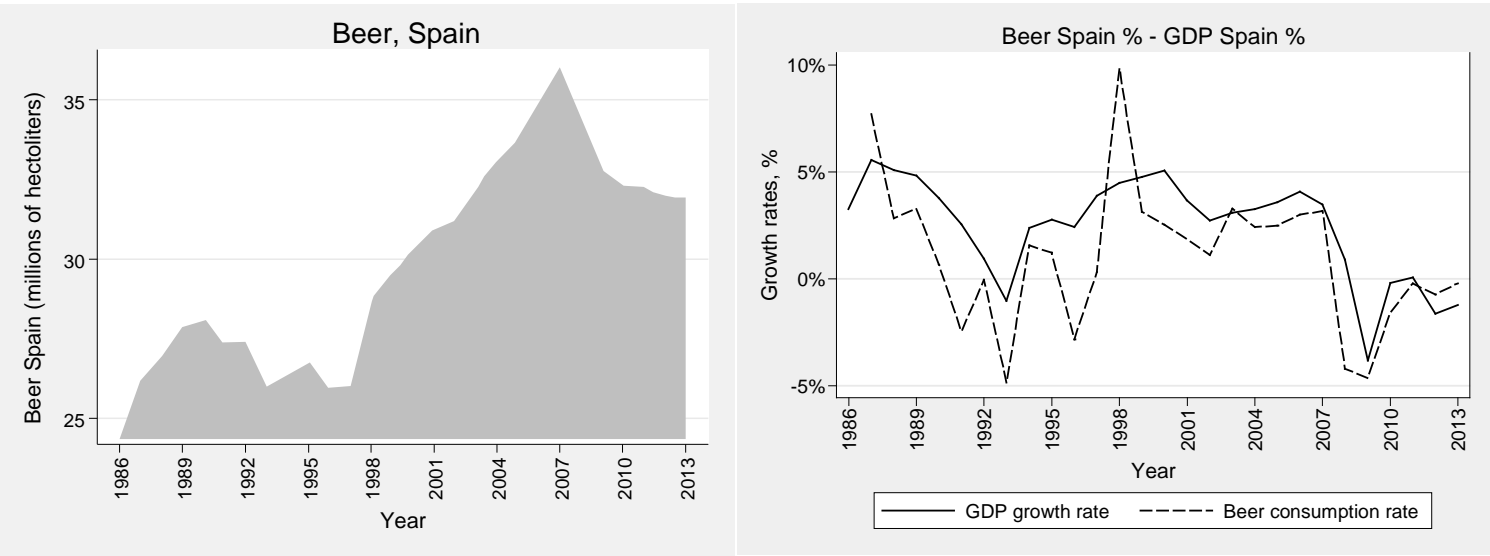

Source: Own elaboration based on Consejo Regulador del Cava, "Cava Shipments in 2013" and "Cava shipments in 2010, http://www.crcava.es/english/bodegas.htm, last access July 2015 and on Organisation for Economic Co-operation and Development (OECD), Statistics section, http://stats.oecd.org/, last access, July 2015. 
In fact, in the period 1987 to 2013, the Spanish domestic beer market grew at an average growth rate of $1.06 \%$, while considerable fluctuations are recorded around this level. The business cycle is responsible for $54.4 \%$ of the total variance. But beyond market conditions, other factors could be linked to these fluctuations. These include the 1996-98 campaigns against alcohol consumption, especially among the young, and the 2003 heat wave.

- The 1996-98 campaigns against alcohol consumption. In the period from 1996 to 1998, growth in beer consumption declines counter to the economic conditions, only to continue its momentum after 1998. A possible explanation for the temporary change in consumer habits is the preventive alcohol policy, which was implemented in terms of educational projects, legislative steps and preventive measures during that same period. The program for community action on health promotion, information, education and training included the promotion of the examination, assessment and exchange of experience and support for actions concerning measures to prevent alcohol abuse and related social and health problems. As a step in this direction, the European Commission invested nearly $€ 1.5$ billion to cofund 12 alcohol projects from 1995 to 1998 (Hurst, Gregory and Gussman, 1997).

In 1995, Spanish authorities approved a road safety plan that included a number of measures aimed at reducing the incidence of driving under the influence of alcohol. Breathalyzers were introduced to measure blood alcohol concentration (BAC) levels (Hurst, Gregory and Gussman, 1997). The national government also conducted advertising campaigns aimed at preventing alcohol-related traffic accidents. For instance, during the 1995 Christmas period the Basque regional government ran a campaign against drunk driving targeted at young people, which included advertising and programs at discos. Further, in 1996, the Valencia region introduced a dry law for those under 16 years of age. The legislation introduced fines of up to 10 million pesetas for selling alcoholic drinks to someone under age, while the offending establishment faced closure for up to two years. The sale of alcoholic beverages at educational centers was banned (Hurst, Gregory and Gussman, 1997). In addition, in 1995, the Spanish Brewers Association signed a self-regulation code that included a responsible consumption message in all commercial communications. The Spanish Advertisers' Association's Code for the Self-Regulation of the Advertising of Alcoholic Drinks was adopted in 1996 by the Spanish Federation of Drinks Producers (European Alcohol Policy Alliance). The code covered alcoholic beverage advertising and young people, driving, health, work, social behavior, alcoholic strength and sport.

We expect these active measures to have had an impact on the consumption of alcoholic beer. Vendors would be more cautious in selling beer to minors, drivers would consider more carefully the amount of alcohol they consume prior to driving, on account of safety and legal considerations, and, in general, increased health consciousness would moderate alcohol consumption. Thus, we control for the implementation of the preventive alcohol policy in Spain as an external shock affecting beer consumption for the period from 1996 to 1998 , using dummy variables. The first two years represent the exogenous shock on consumption whereas 1998 marks the resumption of the growth trend. Official reports attest to the fact that, beyond the initial reaction to these policy measures, formal control has not been strong on alcohol-related issues. Thus, the concerns of vendors and drivers subsided over time.

- The 2003 heat wave. Another factor influencing beer consumption is the weather. Warm temperatures are associated with increased beer consumption. The unusually high temperatures and prolonged summer period in 2003, also referred to as the 2003 European heat wave, had a positive effect on beer consumption, which grew by $3.27 \%$ in Spain. The 
following year marked a downward revision, correcting for the effects of unusual weather in 2003. In our analysis, we control for weather phenomena using dummies for 2003 and 2004. After performing the analysis, the year 2004 has no significant effect and hence we drop it.

The results are depicted in Table B1. We can conclude from this analysis that the exposure of the Spanish beer industry to the economic cycle is $77.8 \%$. The intensity of the exposure of this industry to the business cycle in percentage terms is 0.95. This means that for each extra percentage point increase in Spanish GDP the growth rate of the consumption of beer in Spain increases by 0.95 percentage points, which in absolute terms means around 305,000 hectoliters. Ariño et al. (2008) report a lower exposure of 67\%, and a higher intensity of 1.38, which translates into 373,000 hectoliters, according to 1998 consumption levels. The results of the two papers are comparable. In absolute terms, the Spanish beer industry is affected less by the business cycle, which may represent the increased appeal of the industry to the tastes of consumers.

\section{Table B1}

OLS regressions of the rate of change in the sales of beer, Spain, 1987-2013

\begin{tabular}{|c|c|c|c|c|c|}
\hline Variable & $\begin{array}{c}\text { Model 1: } \\
\text { Benchmark }\end{array}$ & $\begin{array}{c}\text { Model 2: } \\
\text { Preventive } \\
\text { measures }\end{array}$ & $\begin{array}{l}\text { Model 3: } \\
\text { End of } \\
\text { measures }\end{array}$ & $\begin{array}{l}\text { Model 4: } \\
\text { Heat wave }\end{array}$ & $\begin{array}{l}\text { Model 5: } \\
\text { Final }\end{array}$ \\
\hline GDP growth rate & $\begin{array}{c}1.032^{* * *} \\
(5.83)\end{array}$ & $\begin{array}{c}1.057^{\star \star \star \star} \\
(5.84)\end{array}$ & $\begin{array}{c}0.934^{\star * \star *} \\
(6.00)\end{array}$ & $\begin{array}{c}1.022^{\star \star \star} \\
(5.41)\end{array}$ & $\begin{array}{c}0.949 \star \star \star \\
(5.82)\end{array}$ \\
\hline Year 1996 & & $\begin{array}{c}-4.133^{\star \star *} \\
(-8.99)\end{array}$ & & & $\begin{array}{c}-3.781^{\star * *} \\
(-9.57)\end{array}$ \\
\hline Year 1997 & & $\begin{array}{c}-2.525^{\star \star \star} \\
(-4.37)\end{array}$ & & & $\begin{array}{c}-2.016^{\star \star *} \\
(-4.45)\end{array}$ \\
\hline Year 1998 & & & $\begin{array}{l}7.144^{\star \star *} \\
(14.73)\end{array}$ & & $\begin{array}{c}6.955^{\star \star \star} \\
(13.67)\end{array}$ \\
\hline Year 2003 & & & & $\begin{array}{c}1.610^{\star * *} \\
(2.96)\end{array}$ & $\begin{array}{c}1.684^{\star \star \star} \\
(4.14)\end{array}$ \\
\hline Year 2004 & & & & $\begin{array}{l}0.577 \\
(1.03)\end{array}$ & \\
\hline$R^{2}$ (exposure) & $54.40 \%$ & $61.84 \%$ & $70.74 \%$ & $55.34 \%$ & $77.76 \%$ \\
\hline Intensity (hl) & 331,857 & 339,896 & 300,343 & 328,641 & 305,167 \\
\hline
\end{tabular}

${ }^{*} p<0.10 ;{ }^{* *} p<0.05 ;{ }^{* * *} p<0.01$

Source: Own elaboration based on Euromonitor International, http://www.euromonitor.com/passport, last access July 2015.

\section{Sales Channels}

Beer sales are directed through on-trade and off-trade channels. On-trade refers to beer sales through licensed restaurants, bars and pubs. Off-trade sales, a smaller proportion of overall sales, are facilitated through supermarkets and other vendors and consumed elsewhere, usually at home. Since 2000, off-trade sales in Spain have enjoyed a continuous rise, climbing from $29.7 \%$ to $43.3 \%$ of total sales. Figure B3 attests to this increase. Further, within the context of the economic crisis, the balance between on-trade and off-trade sales of beer has been gradually shifting in favor of the off-trade channel. While on-trade sales accounted for $64 \%$ of total beer volume sales in 2008 , by 2013 this proportion fell to $57 \%$. In response to this trend, producers are increasingly using their advertising campaigns to encourage the general consumption of beer in bars. 
Overall, the declines recorded in sales of beer through the on-trade channel were compensated for by improving sales through off-trade channels. We observe that Spaniards seem to be generally reducing their expenditure on drinking outside the home, preferring to relax in their own surroundings with family and friends.

\section{Figure B3}

On-trade and off-trade beer sales, Spain

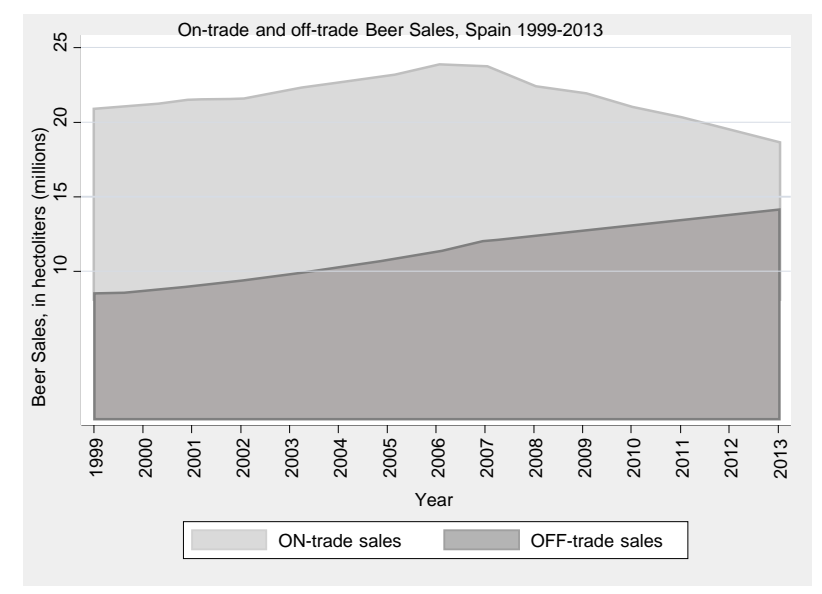

Source: Own elaboration based on Euromonitor International, http://www.euromonitor.com/passport, last access July 2015.

Upon decomposition of the dependent variable (beer sales) into on-trade and off-trade volumes, it becomes clear that fluctuations of on-trade sales are more exposed to transient industry effects than off-trade sales are. Table B2 shows exposure for on-trade sales to be $65.5 \%$, and for offtrade sales it is $45.9 \%$. Even though off-trade sales exhibit reasonable exposure, the intensity of this exposure to transient industry effects is much lower at 0.278 , compared with on-trade sales' intensity of 0.935 . This reveals a much weaker relationship between the business cycle and offtrade sales, which affects the overall results for the period 2000 to 2013. In effect, without controlling for any exogenous shocks, the business cycle accounts for $46 \%$ to $66 \%$ of variance in beer sales in Spain, depending on the channel.

\section{Figure B4}

GDP growth rates, off-trade beer consumption rate and on-trade beer consumption rate

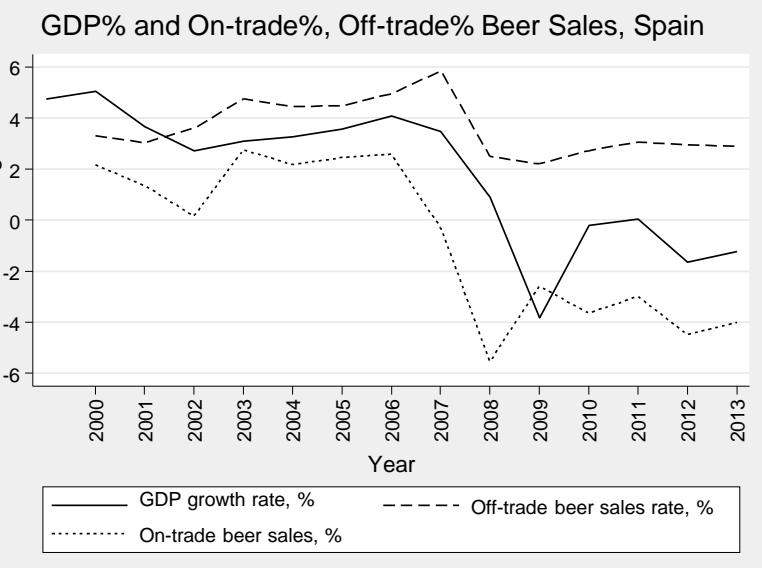

Source: Own elaboration based on Euromonitor International, http://www.euromonitor.com/passport, last access July 2015 and on Organisation for Economic Co-operation and Development ( $\overline{\mathrm{OECD}}$ ), Statistics section, http://stats.oecd.org/, last access, July 2015. 


\section{Table B2}

OLS regressions of the rate of change in beer consumption by sales channel, 2000-13

\begin{tabular}{lccc}
\hline Variable & $\begin{array}{c}\text { Model 1: } \\
\text { Total sales }\end{array}$ & $\begin{array}{c}\text { Model 2: } \\
\text { On-trade }\end{array}$ & $\begin{array}{c}\text { Model 3: } \\
\text { Off-trade }\end{array}$ \\
\hline GDP growth rate & $0.655^{\star \star \star}$ & $0.935^{\star \star \star}$ & $0.278^{\star \star \star}$ \\
& $(4.69)$ & $(4.04)$ & $(3.64)$ \\
$\mathrm{R}^{2}$ (exposure) & $65.34 \%$ & $65.53 \%$ & $45.86 \%$ \\
\hline Intensity & 220,711 & 178,586 & 40,577 \\
\hline
\end{tabular}

${ }^{*} \mathrm{p}<0.10 ;{ }^{* *} \mathrm{p}<0.05 ;{ }^{* * *} \mathrm{p}<0.01$

Source: Own elaboration based on Euromonitor International, http://www.euromonitor.com/passport, last access July 2015.

\section{Spanish Cava and Beer}

In evaluating the magnitude of transient industry effects in the Spanish cava and beer industries we observe high exposures for both industries, consistent with the results of Ariño et al. (2008). In terms of the intensity of the exposure, we note that it is considerably smaller for beer (0.95) than for cava (1.47). The intensity of exposure reflects the responsiveness to fluctuations in the business cycle and this differs for the two products because of their different characteristics. Beer is enjoyed at more informal settings and its consumption spreads out to a daily or weekly basis, rendering it more of a habitual drink. As a result, beer consumption can be moderated instead of suppressed in times of economic hardship. On the contrary, Spanish culture embraces the enjoyment of cava at special occasions such as weddings, birthdays and Christmas. Because of its higher price, cava is more prone to budget considerations and constraints. Alternative explanations include the effect of the availability of draft beer, for which our data do not account.

\section{ii. UNITED KINGDOM}

The consumption of alcohol, including beer, has long been an important part of traditional culture in the United Kingdom. The United Kingdom has a long history of beer production and domestic beer dominates the beer market. There are many varieties of beer produced in the United Kingdom including bitters, stouts, lagers, ales and milds. Beer is traditionally consumed by the glass in pubs (Hurst, Gregory and Gussman, 1997). The United Kingdom accounts for $15.1 \%$ of the European market in 2012 and standard lager is the dominant category, responsible for 70\% of total beer volume sales in the United Kingdom (Euromonitor, 2014). Within this category, domestic standard lager accounts for half of the volume sales. Nonetheless, imported premium lager is gaining popularity among U.K. consumers.

The U.K. beer industry remains fairly consolidated, with the top five companies accounting for $77 \%$ of total volume sales in 2013. Heineken U.K. Ltd. leads the category with a total volume share of 22\%, followed by InBev U.K. Ltd. and Molson Coors Brewing Co. (U.K.) Ltd. at 19\% each. Carlsberg (U.K.) Ltd. accounts for $11.9 \%$ of total volume sales. The leading beer brands in the United Kingdom are Carling and Foster's, both positioned within the standard lager price band.

In the case of the United Kingdom, our data date back to 1960. In view of the evolution of the activity of the beer industry, as depicted in the graph in Figure B5, we can be confident that the growth phase of the industry concluded just before 1980 . The beer industry reached its peak in 
1979, thereafter entering a phase of stable growth or maturity. In 2004, there was another peak of beer sales in the United Kingdom, the last one to date, followed by steady decline.

\section{Figure B5}

Beer consumption in the United Kingdom, 1960-2013

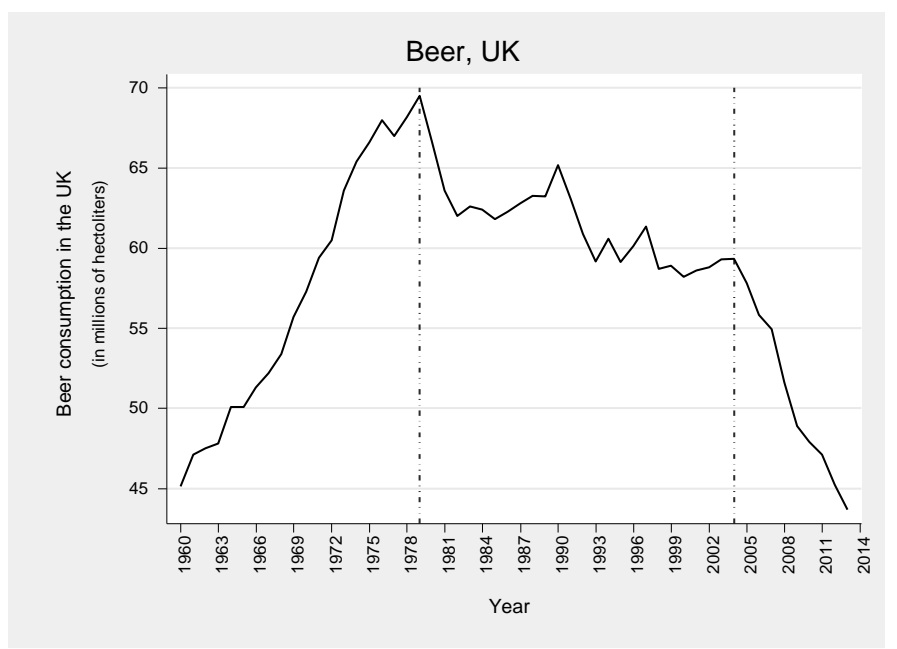

Source: Own elaboration based on Euromonitor International, http://www.euromonitor.com/passport, last access July 2015.

Our analysis excludes the growth phase of the industry over which the transient industry effects model is not applicable. Hence, we analyze the U.K. beer industry over the period 1980 to 2013. Figure B6 depicts the coevolution of the two rates over this period. The average growth rate of beer consumption over this period of $-1.33 \%$ is indicative of an overall declining trend in the industry; this does not affect our analysis since we are looking at growth rates that are inherently detrended. Further, the rate of beer consumption appears more volatile than the GDP rate, with its variance rising to 6.5 whereas the variance of GDP rate is 5.1.

\section{Figure B6}

United Kingdom, \% GDP and \% beer consumption

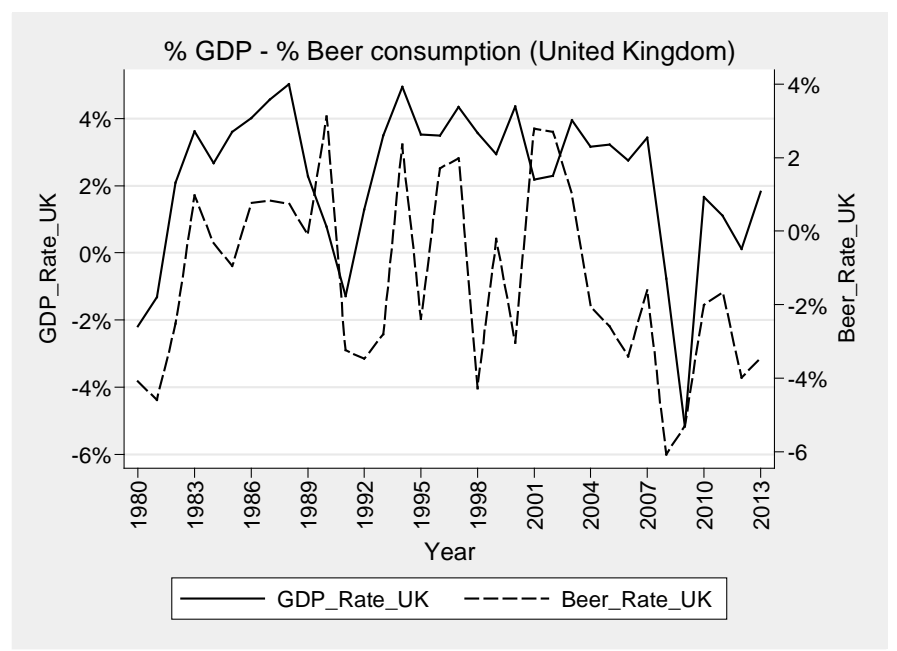

Source: Own elaboration based on Euromonitor International, http://www.euromonitor.com/passport, last access July 2015 and on Organisation for Economic Co-operation and Development (OECD), Statistics section, http://stats.oecd.org/, last access, July 2015. 
We proceed to investigate the change in the relationship of GDP and beer sales in the United Kingdom from 1980 to 2013. Since we have no evidence or theory for a lagged relationship, we allow for a synchronized relationship and account for the different shocks during our period of study. We identify each shock separately, based on public knowledge of historic events in the United Kingdom and market reports. In this way, we identify a list of shocks to the U.K. beer industry in the years 1991-92, 2003-04, and 2008.

- The U.K. recession of 1991-92. The late 1980s were a period of rapid economic expansion for the United Kingdom, caused by rising house prices, tax cuts, lower interest rates and high confidence. Growth reached record levels of 5\% to 6\% a year, but by the end of the $1980 \mathrm{~s}$ inflation was getting out of control and it climbed to 9.5\% in 1990. In order to reduce inflation, the United Kingdom joined the exchange rate mechanism (ERM), a mechanism designed as a precursor to joining the euro with the aim of keeping exchange rates stable and inflation at low levels. In the ERM, the value of the pound sterling was kept within certain boundaries against the deutsche mark. However, with inflation increasing the pound became weak on the exchange markets. Therefore, the government was forced to increase interest rates to protect the value of the pound from falling. Higher interest rates (set at 15\%) were helpful for reducing inflation but, as a side effect, high rates caused a big increase in the cost of mortgage payments, which led to home repossessions and falling house prices. Falling house prices and lower consumer spending caused the economy to slow down and enter a recession. The country experienced a significant wave of rioting at the height of the recession in 1991 and 1992, with unemployment and social discontent being seen as major factors. However, despite the economy entering a recession, the government was slow to cut interest rates, as it placed greater value on the exchange rate target than economic growth. Eventually the government was forced to give up its misplaced efforts to maintain a high exchange rate. The United Kingdom left the ERM and interest rates were able to fall. The pound retreated by 15\%, interest rates were cut, and the economy was able to recover in the following years. Controlling for the recession using dummies for 1991 and 1992, we note that only 1992 is statistically significant, indicating that U.K. consumers decreased beer consumption only as the recession deepened.

- The 2003 heat wave. In addition, we control for the weather and the 2003 European heat wave, since warmer summer temperatures are generally associated with increased beer consumption. In the case of the United Kingdom, the favorable weather conditions merely stalled the downtrend of beer consumption as measured in hectoliters (volume). In our analysis, we control for weather phenomena using dummies for 2003 and 2004.

- The 2008 beer duty. One of the key concerns of U.K. beer industry representatives has been the government's escalator policy of annual above-inflation rises in beer duty. The policy led to a $35 \%$ rise in beer duty over the period 2008 to 2012. The policy came to an end in 2013. It is worth considering whether the change in the price of beer affected U.K. consumers temporarily or permanently. In the first scenario, consumers are initially affected by the price increase but later adjust. In our analysis, we would control for the rise in beer duty as a temporary exogenous shock, by introducing an independent variable in the form of a dummy for the year 2008. Alternatively, in the second scenario, a lasting change in consumer behavior would be reflected by a structural change starting in 2008; we would model the permanent change using a dummy variable that takes the value 1 for the period 2008 to 2013, otherwise 0 . The results from the second model are weaker both in terms of exposure and intensity. Hence, in our analysis, we choose to treat the rise in beer duty as a temporary shock to which U.K. consumers adjust in the next period (a dummy that takes the value 1 for the year 2008, otherwise 0).

IESE Business School-University of Navarra - 17 
The relationship between the U.K. beer industry and the business cycle is presented in Table B3. Without any adjustment, the exposure of the U.K. beer industry to the economic cycle is $32 \%$. Controlling for the recession in 1992, the heat wave in 2003, and the increase in beer duty in 2008 we find the exposure of the U.K. beer industry to the economic cycle to be $39.1 \%$. The intensity of the exposure of this industry to the business cycle in percentage terms is 0.57 . This means that, for each percentage point increase in U.K. GDP, the growth rate of beer consumption is 0.57 percentage points. As the 2013 level of consumption is 43.7 million hectoliters, an extra percentage point in the growth rate of U.K. GDP translates to an additional consumption of 248,000 hectoliters of beer.

\section{Table B3}

OLS regressions of the rate of change in beer sales, United Kingdom, 1980-2013

\begin{tabular}{|c|c|c|c|c|c|}
\hline Variable & $\begin{array}{c}\text { Model 1: } \\
\text { Benchmark }\end{array}$ & $\begin{array}{l}\text { Model 2: } \\
\text { Recession }\end{array}$ & $\begin{array}{l}\text { Model 3: } \\
\text { Heat wave }\end{array}$ & $\begin{array}{l}\text { Model 4: } \\
\text { Beer duty }\end{array}$ & $\begin{array}{l}\text { Model 5: } \\
\text { Final }\end{array}$ \\
\hline GDP growth rate & $\begin{array}{c}0.639 * * * \\
(5.58)\end{array}$ & $\begin{array}{c}0.637^{\star \star \star} \\
(4.99)\end{array}$ & $\begin{array}{c}0.634^{\star \star \star} \\
(5.27)\end{array}$ & $\begin{array}{c}0.584^{\star \star \star} \\
(5.57)\end{array}$ & $\begin{array}{c}0.568^{\star \star \star} \\
(5.03)\end{array}$ \\
\hline Year 1991 & & $\begin{array}{l}0.285 \\
(0.46)\end{array}$ & & & \\
\hline Year 1992 & & $\begin{array}{c}-1.587^{\star \star *} \\
(-3.75)\end{array}$ & & & $\begin{array}{c}-1.765^{\star *} \\
(-4.27)\end{array}$ \\
\hline Year 2003 & & & $\begin{array}{c}1.250^{\star *} \\
(2.65)\end{array}$ & & $\begin{array}{c}1.214^{\star *} \\
(2.47)\end{array}$ \\
\hline Year 2004 & & & $\begin{array}{c}-1.336 * \star \star * \\
(-3.13)\end{array}$ & & $\begin{array}{c}-1.423^{\star \star \star \star} \\
(-3.16)\end{array}$ \\
\hline Year 2008 & & & & $\begin{array}{c}-3.084^{\star \star \star} \\
(-6.80)\end{array}$ & $\begin{array}{c}-3.194^{\star \star \star} \\
(-6.52)\end{array}$ \\
\hline$R^{2}$ (exposure) & $32.03 \%$ & $33.21 \%$ & $33.58 \%$ & $36.10 \%$ & $39.10 \%$ \\
\hline Intensity (hl) & 279,053 & 278,180 & 276,870 & 255,035 & 248,047 \\
\hline
\end{tabular}

${ }^{*} p<0.10 ;{ }^{* *} p<0.05 ;{ }^{* * *} p<0.01$

Source: Own elaboration based on Euromonitor International, http://www.euromonitor.com/passport, last access July 2015 and on Organisation for Economic Co-operation and Development (OECD), Statistics section, http://stats.oecd.org/, last access, July 2015.

Our findings indicate a weak relationship between the U.K. beer industry and the business cycle, which can be explained by the changing trends among U.K. consumers. In particular, the low exposure prevalent in the U.K. beer industry has its roots in the premiumization trend, whereby consumers are becoming more discerning and favoring quality over quantity. Imported premium lager is gaining popularity among U.K. consumers, at the expense of domestic standard lager. This trend has had an inverse impact on volume and value sales, with the former declining but the latter growing. Thus, the effect of the business cycle on beer consumption, measured in either volume or value, is obscured by substitution between beer categories, and this may explain why the exposure found is not stronger. 
In fact, our measure of beer is an aggregate of dark beer (or ale), lager and stout. Decomposing the measure according to this category segmentation, for the period 2008 to 2013 over which we have category-level data, we find the exposure of the rate of lager sales to the business cycle to be quite strong at 51\%. At the same time, the rates of both ale and stout sales demonstrate very low exposures (4.9\% and 27\%, respectively). This suggests that U.K. consumers distinguish between beer categories and tend to favor quality over quantity.

Another possible explanation lies in the increasing use of price promotions following the introduction of the beer duty escalator, in an effort to mitigate the burden on the consumer. Price promotions resulted in a blurring of the price bands within lager, with premium brands such as Budweiser, Beck's and Kronenbourg 1664 heavily discounted to the point of being sold at a lower price than standard lagers in many shops.

Finally, the proportion of off-trade vs. on-trade volume sales has remained steady even throughout the financial crisis, with the on-trade sales slightly dominating by 53\%. This indicates that U.K. consumers did not change their tradition of going to the pub after work or on the weekend.

\section{iii. GERMANY}

Germany is a country with a tolerant attitude towards alcohol consumption and beer is a major part of German culture. The positive attitude of the majority of the population makes it in fact rather difficult to refuse a drink in public. In Germany there are almost no restrictions on consumption patterns. An early morning drink is as commonly accepted as drinking in the evening or while having lunch or supper or while watching television, as well as the drinking of small amounts of alcohol distributed over the whole day.

Germany accounts for 17.5\% of the European market (Euromonitor, 2014). Lager is by far the largest category in the German beer environment with 79\% of total volume sales, mainly due to the most popular beer type, Pils. Within lager, domestic premium lager is the largest category in terms of volume sales with a share of 53\%, followed by domestic economy lager, which accounts for 15\% of lager volume sales. The competitive landscape in the German beer category is highly fragmented. Radeberger Gruppe KG leads with a total volume share of 12\% in 2013. The four largest players hold only $32 \%$ of the total market volume.

In Germany, our data cover a period where the industry is following a path of decline and is approaching stagnation, with average negative growth of 1.32\%. Figure B7 shows the evolution of the German beer market over our period of study, and Figure B8 depicts the coevolution of the industry and the business cycle. We note the continuous downward trend and negative growth rates in beer consumption (with the exception of an increase in 2006). Germans show no responsiveness to the 2003 hot summer; unlike consumers elsewhere, Germans do not drink more beer just because the weather is warmer and they can enjoy more hours in the sun. This unusual behavior is indicative of both the stagnation of the industry as well as the German culture of consuming beer anywhere and anytime. 


\section{Figure B7}

Beer consumption in Germany, 1998-2013

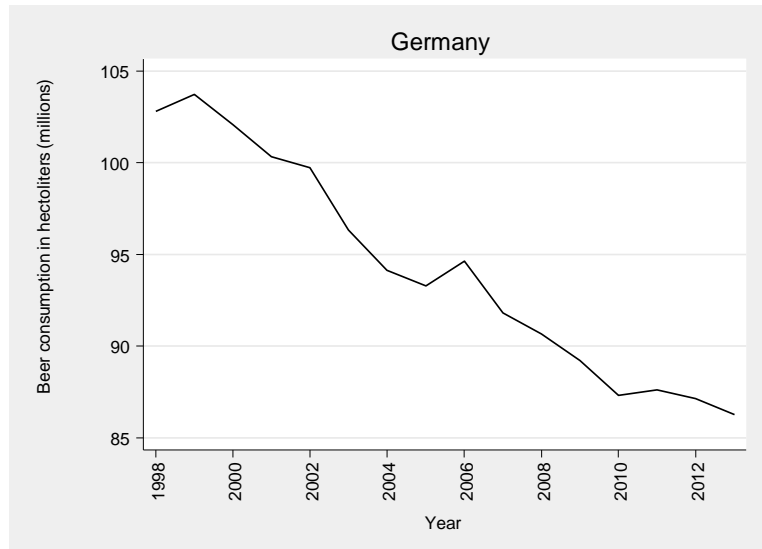

\section{Figure B8}

Germany, \% GDP and \% beer consumption

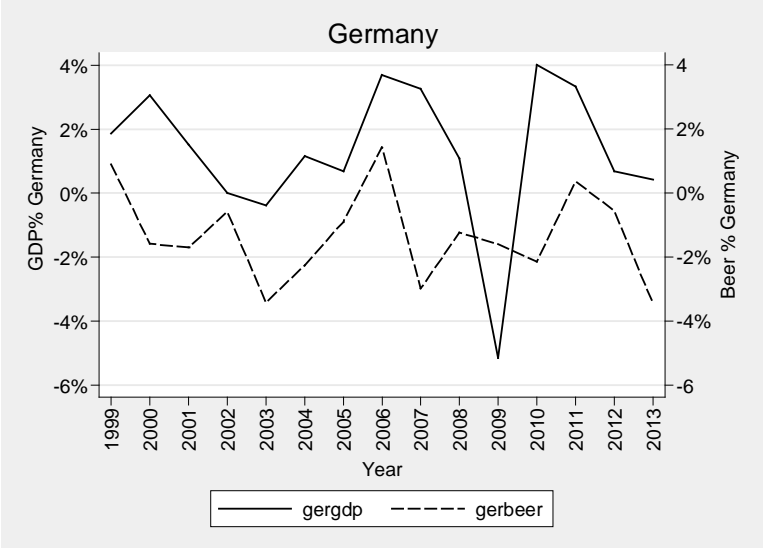

Source: Own elaboration based on Euromonitor International, http://www.euromonitor.com/passport, last access July 2015 and on Organisation for Economic Co-operation and Development (OECD), Statistics section, http://stats.oecd.org/, last access, July 2015.

\section{Beer Consumption}

In our analysis, we identify and control for the exogenous event in 2006 affecting beer consumption, the World Cup. In 2006, there is a rise in beer consumption in Germany, which can be attributed to the 2006 FIFA World Cup that the country was hosting. Considering the strong soccer tradition across generations of Germans, the popularity of beer as an accompaniment to watching the games, as well as the influx of soccer fans from all over the world, the increase in beer sales could be explained by the World Cup. At the same time, economic activity picked up as the four-week tournament contributed much to Germany's tourism, retail industry and employment rate.

The relationship between the German beer industry and the business cycle is presented in Table B4. Without any adjustment, the exposure of the German beer industry to the economic cycle is 5.4\%. Controlling for the World Cup in 2006, we find the exposure of the German beer industry to the economic cycle to be $27.5 \%$. The intensity of the exposure of this industry to the business cycle in percentage terms is very low at 0.06 . This means that, for each percentage point increase in U.K. GDP, the growth rate of beer consumption is 0.06 percentage points. As the 2013 level of consumption is 86.3 million hectoliters, an extra percentage point in the growth rate of German GDP translates into an additional consumption of less than 49,000 hectoliters of beer. 


\section{Table B4}

OLS regressions of the rate of change in beer sales, Germany, 1999-2013

\begin{tabular}{lcc}
\hline Variable & $\begin{array}{c}\text { Model 1: } \\
\text { Benchmark }\end{array}$ & $\begin{array}{c}\text { Model 2: } \\
\text { World Cup }\end{array}$ \\
\hline GDP growth rate & 0.150 & 0.057 \\
Year 2006 & $(0.99)$ & $(0.48)$ \\
& & $2.794^{\star \star \star}$ \\
$\mathrm{R}^{2}$ (exposure) & & $(5.15)$ \\
\hline Intensity (hl) & $5.40 \%$ & $27.49 \%$ \\
\hline
\end{tabular}

${ }^{*} p<0.10 ;{ }^{* *} p<0.05 ;{ }^{* * *} p<0.01$

Source: Own elaboration based on Euromonitor International, http://www.euromonitor.com/passport, last access July 2015 and on Organisation for Economic Co-operation and Development (OECD), Statistics section, http://stats.oecd.org/, last access, July 2015.

Our results lack economic significance, which suggests that the relationship between the German beer market and the business cycle is not very strong. A possible explanation is the stagnation of the German beer market as evidenced by the negative average growth over this period. According to trade press reports, market stagnation stems from the increasing health consciousness of German consumers and therefore their more moderate consumption of beer. In addition, among the younger generation, there is an increasing substitution effect from beer to other beverages. Another characteristic of the German beer market is that the off-trade is the larger channel in Germany with 64\% of total volume sales (Euromonitor, 2014). On-trade volume sales declined by 10.5\% over the period 2008 to 2013, more than double the rate of decline of off-trade sales (5.1\%). Germans are no longer honoring the tradition of going to the pub after work or on the weekend, which negatively affects on-trade volume sales.

\section{iv. FRANCE}

France accounts for only 4.9\% of the European beer market value (Euromonitor, 2014). Beer is most often drunk as an aperitif or convivial drink with relatives, friends and colleagues. But unlike people from the rest of Europe, French people do not consider beer as an accompaniment to meals. Lager accounts for 82\% of total volume sales in France. Premium lager is the largest segment of the beer market in France, and this includes flavored or mixed lager, for which the French have an affinity. Premium lager sales in 2013 accounted for more than half the total lager volume in 2013.

In 2013, Heineken Entreprise SAS conquered the beer volume leadership in France with 31\% of total sales. Brasseries Kronenbourg SA followed closely with 30.9\%. The top four biggest players in French beer are international manufacturers, which together captured 74\% of total beer sales in 2013. The most significant domestic manufacturers are Brasserie Duyck SA, Brasserie de SaintOmer and Brasserie Meteor SA, each holding a volume share of less than 1\%.

The on-trade channel has been in structural decline for the past decade mainly due to the fall in the visit rate of cafés and restaurants as a result of the high level of frugality brought about by the economic downturn. Since 2008, on-trade sales have declined by $12.5 \%$ and, in 2013, offtrade beer sales accounted for over 75\% of total volume. Figure B9 shows the evolution of the French beer market over our period of study, and Figure B10 depicts the changes in GDP and beer consumption rates. 


\section{Figure B9}

France, beer consumption, 1998-2013

\section{Figure B10}

France, $\%$ GDP and \% beer consumption
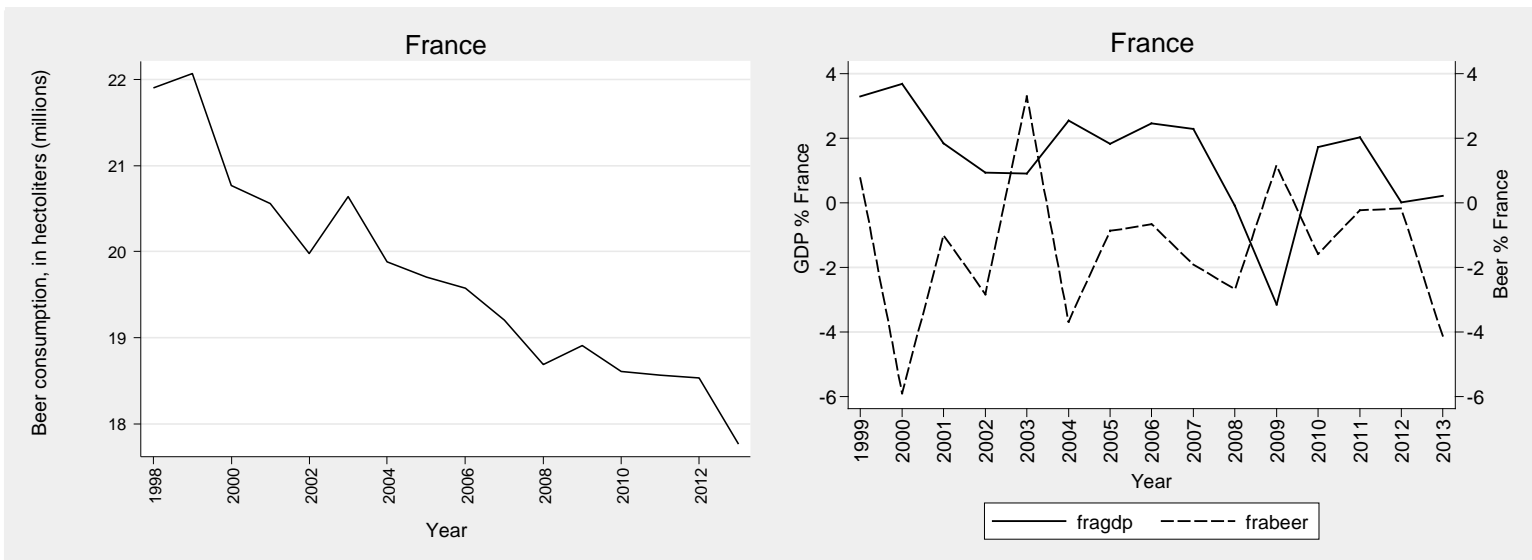

Source: Own elaboration based on Euromonitor International, http://www.euromonitor.com/passport, last access July 2015 and on Organisation for Economic Co-operation and Development (OECD), Statistics section, http://stats.oecd.org/, last access, July 2015.

In our analysis, we identify and control for the following exogenous events affecting beer consumption:

- The 2003 heat wave

- The 2013 introduction of excise duties 160\% higher than the previous year

Table B5 presents the numerical results. The slope coefficients are statistically nonsignificant, which prevents us from analyzing the relationship between beer consumption by the French and the business cycle. The negative sign, however, is of great interest as it reveals a countercyclical trend and possible substitution effects with other alcoholic beverages.

In France, the beer market is highly atypical in comparison to that of other countries, and buying behaviors confirm the exception that French consumers have a very specific rapport with beer consumption. In particular, French consumers have a strong preference for premium beers, and have continued to favor this category despite new excise duties in 2013 that were 160\% higher than the previous year. This superpremiumization of the category, as referred to by the trade press, means that, instead of shifting part of their consumption onto potentially less expensive lagers, French consumers have maintained and reinforced their preference for premium beers, at the expense of drinking less. Further, beer consumption by the French is largely vulnerable to the threat from substitutes, such as spirits and more especially wine, due to the low switching costs and consumption patterns of the French.

Superpremiumization and product substitution in France account for the poor exposure of the number of hectoliters consumed to the business cycle (10.1\%), as well as the lack of significance in explaining beer consumption from the GDP growth rate. After correcting for the increase in price in 2013 by introducing a dummy for the year, as well as the 2003 heat wave, exposure rises to $56 \%$ but the results remain nonsignificant. 


\section{Table B5}

OLS regressions of the rate of change in beer sales, France, 1999-2013

\begin{tabular}{lcccc}
\hline Variable & $\begin{array}{c}\text { Model 1: } \\
\text { Benchmark }\end{array}$ & $\begin{array}{c}\text { Model 2: } \\
\text { Heat wave }\end{array}$ & $\begin{array}{c}\text { Model 3: } \\
\text { Beer duty }\end{array}$ & $\begin{array}{c}\text { Model 4: } \\
\text { Final }\end{array}$ \\
\hline GDP growth rate & -0.435 & -0.328 & -0.542 & -0.425 \\
Year 2003 & $(-1.35)$ & $(-0.85)$ & $(-1.71)$ & $(-1.18)$ \\
Year 2004 & & $4.709^{\star \star \star}$ & & $4.413^{\star \star \star}$ \\
& & $(8.59)$ & & $(9.04)$ \\
Year 2013 & $-1.731^{\star}$ & & $-1.868^{\star}$ \\
& & $(-1.97)$ & & $(-2.07)$ \\
$\mathrm{R}^{2}$ (exposure) & & $-3.655^{\star \star \star}$ & $-3.328^{\star \star \star}$ \\
\hline Intensity (hl) & $10.10 \%$ & $42.65 \%$ & $26.32 \%$ & $(-6.36)$ \\
\hline
\end{tabular}

${ }^{*} p<0.10 ;{ }^{* *} p<0.05 ;{ }^{* * *} p<0.01$

Source: Own elaboration based on Euromonitor International, http://www.euromonitor.com/passport, last access July 2015 and on Organisation for Economic Co-operation and Development (OECD), Statistics section, http://stats.oecd.org/, last access, July 2015.

\section{v. ITALY}

Italy accounts for 6.7\% of the European market. The preferred category is lager beer, which comprised 92\% of total volume sales in 2013. Standard lager accounted for around 91\% of total beer volume sales in 2013, of which 73\% was domestic lager. Peroni, Moretti and Dreher are the three most popular domestic brands, while Ceres and Bavaria are the most popular imported brands. The leading company for beer in 2013 was Heineken, with a total volume share of 27\%. Birra Peroni was the second player with a $20 \%$ total volume share. The off-trade channel is the main channel for beer sales, accounting for a 64\% share of total volume sales in 2013.

In Italy, beer sales grew by an average of 0.4\% over the period 1999 to 2013, peaking in 2007, just before the onset of the crisis. Figure B11 shows the evolution of beer sales in Italy and Figure B12 graphs the relationship between fluctuations in the economy and the beer industry. The growth of beer sales was highly correlated to the business cycle, with an exposure of 56\% and intensity of 0.9, or 147,000 hectoliters, after correcting for the effect of the hot 2003 summer. Table B6 presents the results. 


\section{Figure B11}

Beer consumption in Italy, 1998-2013

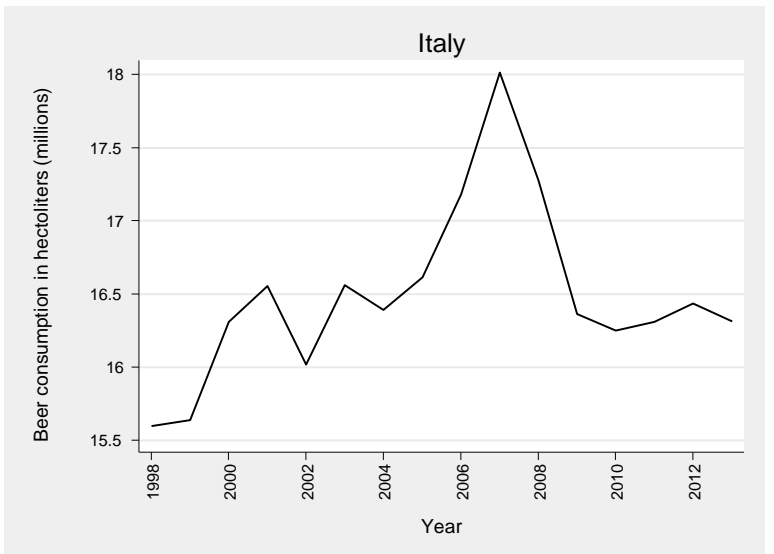

Figure B12

Italy, \% GDP and \% beer consumption

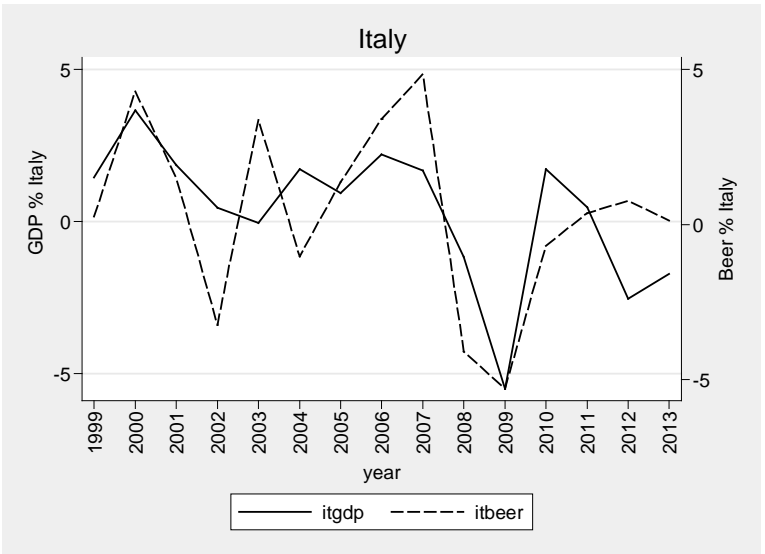

Source: Own elaboration based on Euromonitor International, http://www.euromonitor.com/passport, last access July 2015 and on Organisation for Economic Co-operation and Development (OECD), Statistics section, http://stats.oecd.org/, last access, July 2015.

\section{Table B6}

OLS regressions of the rate of change in beer sales, Italy, 1999-2013

\begin{tabular}{lcc}
\hline Variable & $\begin{array}{c}\text { Model 1: } \\
\text { Benchmark }\end{array}$ & $\begin{array}{c}\text { Model 2: } \\
\text { Heat wave }\end{array}$ \\
\hline GDP growth rate & $0.836^{\star \star \star}$ & $0.904^{\star \star *}$ \\
$(4.17)$ & $(4.35)$ \\
Year 2003 & & $3.391^{\star \star \star}$ \\
Year 2004 & & $(4.99)$ \\
$\mathrm{R}^{2}$ (exposure) & & $-2.622^{\star \star \star}$ \\
Intensity (hl) & $41.02 \%$ & $-3.76)$ \\
\hline
\end{tabular}

${ }^{*} p<0.10 ;{ }^{* *} p<0.05 ;{ }^{* * *} p<0.01$

Source: Own elaboration based on Euromonitor International, http://www.euromonitor.com/passport, last access July 2015 and on Organisation for Economic Co-operation and Development (OECD), Statistics section, http://stats.oecd.org/, last access, July 2015.

\section{vi. UNITED STATES}

Lager is the preferred category of U.S. consumers, with lager sales accounting for $94 \%$ of total beer volume sales in 2013. The top four beer brands in the United States - Bud Light, Budweiser, Coors Light and Miller Lite - are all positioned within the standard lager band, making this the most competitive segment in the country, with a $48 \%$ share of total U.S. beer volume sales (Euromonitor, 2014). Anheuser-Busch InBev is the dominant manufacturer with a $47 \%$ volume share.

The U.S. beer industry is marginally expanding, as domestic beer sales grew at an average of $0.28 \%$ over the period 1999 to 2013. There is a trend for U.S. consumers to move away from beer towards other alcoholic drinks such as wine, cider or perry, and spirits. Young people in particular avoid drinking what their parents drink and are open to other beverage choices. Further, offtrade sales accounted for a 75\% share of total beer sales by volume in 2013, which is not atypical for the United States. 
The U.S. economy was the first to experience the credit crunch, with the initial signs of severe recession appearing in 2007, disrupting the increasing trend for beer sales, which peaked in 2007. U.S. consumers remained confident and were slow to adjust their consumption habits as they had yet to feel any severe repercussions. From 2007 to 2008, the economic growth rate deteriorated from $1.8 \%$ to $-0.3 \%$ thus entering negative territory, whereas beer consumption continued to rise by $1.1 \%$ in 2008. Following the collapse of Lehman Brothers in September 2008, consumer confidence plunged, with beer sales facing successive declines up until 2011. On the other hand, the U.S. economy returned to growth in 2010. But the impact of the crisis was so great, with an adverse impact on the credit, mortgage and employment sectors, that consumers remained cautious before returning to their drinking habits. In fact, consumption levels in 2011 returned to those of 2005, but remained well below the pre-crisis level. Figure B13 shows the evolution of beer sales in the United States and Figure B14 shows the relationship between fluctuations in the economy and the beer industry.

\section{Figure B13}

Beer consumption in the United States, 1998-2013

\section{Figure B14}

United States, \% GDP and \% beer consumption
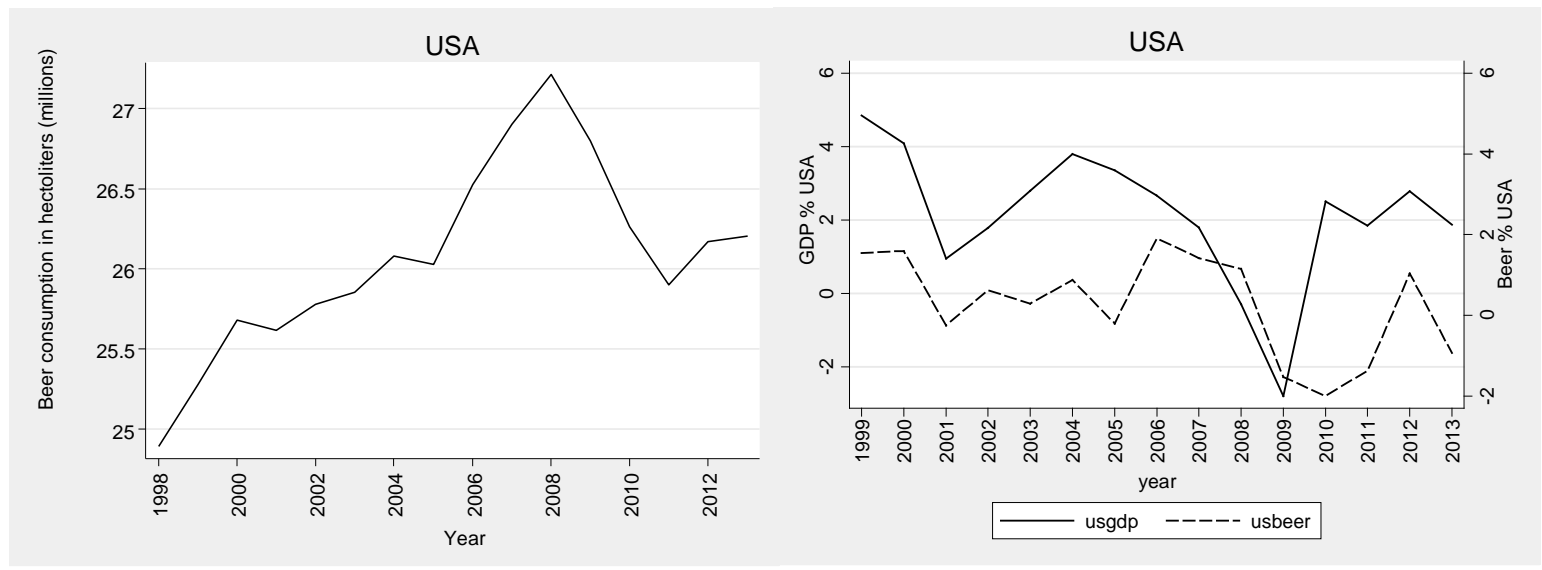

Source: Own elaboration based on Euromonitor International, http://www.euromonitor.com/passport, last access July 2015 and on Organisation for Economic Co-operation and Development (OECD), Statistics section, http://stats.oecd.org/, last access, July 2015.

Between the years 2008 and 2011 we observe a weak relationship between our variables of interest. At the onset of the economic crisis in 2008 when GDP growth enters negative territory $(-0.29 \%)$, beer consumption keeps rising at a rate of $1.15 \%$. In the following years the opposite trend is observed: economic recovery is not immediately accompanied by a rise in beer consumption. A possible explanation is that the increased euphoria created by the property bubble and ease of credit in the years leading to the 2008 crisis prevented a simultaneous adjustment of consumer habits to the worsening economic climate. Later on, the unpleasant effects of the financial crisis, in terms of unemployment, credit problems and increased uncertainty, made people cautious. This caution can be depicted by a lagged reaction of U.S. consumers to the business cycle. Thus, we could be faced with a structural break in the relationship between U.S. beer consumption and GDP over the years 2008 to 2011 (Gujarati, 2007). This is portrayed in Figure B15, where we replaced GDP growth rates from 2008 to 2011 with the corresponding rates of the year before (i.e., one-year lag), and as a result the relationship between our two variable becomes more synchronized. 


\section{Figure B15}

Structural break, 2008-2011

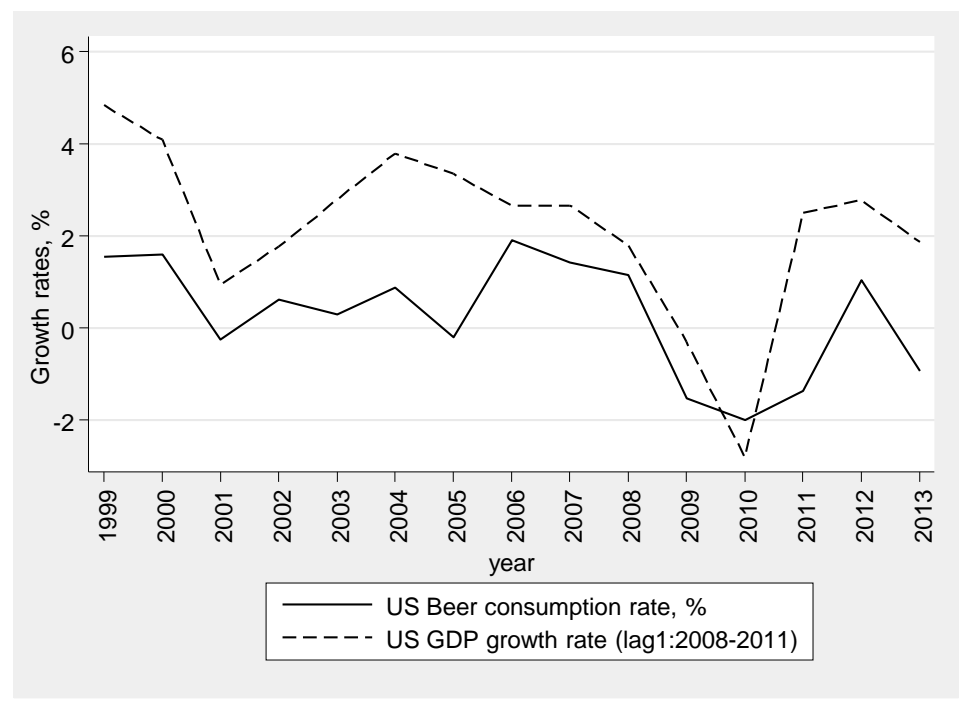

Source: Own elaboration based on Euromonitor International, http://www.euromonitor.com/passport, last access July 2015 and on Organisation for Economic Co-operation and Development (OECD), Statistics section, http://stats.oecd.org/, last access, July 2015.

In our analysis, we correct for the delayed (lagged) behavior of U.S. consumers by introducing lags to account for the lagged reaction of beer sales from 2008 to 2011. Our results are shown in Table B7. The exposure of this industry to the economic cycle is 52.5\%. The intensity of the exposure of this industry to the business cycle in percentage terms is 0.49 . This means that for each extra percentage point of increase in U.S. GDP, the growth rate of the consumption of beer in the United States increases by 0.49 percentage points, which in absolute terms means roughly 1.3 million hectoliters.

\section{Table B7}

OLS regressions of the rate of change in beer sales, United States, 1999-2013

\begin{tabular}{|c|c|c|}
\hline Variable & $\begin{array}{c}\text { Model 1: } \\
\text { Benchmark }\end{array}$ & $\begin{array}{c}\text { Model 2: } \\
\text { Structural break }\end{array}$ \\
\hline GDP growth rate & $\begin{array}{c}0.300^{\star *} \\
(2.77)\end{array}$ & \\
\hline GDP lag (1): 2008-2011 & & $\begin{array}{l}0.489 * \star \star \\
(8.81)\end{array}$ \\
\hline$R^{2}$ (exposure) & $19.74 \%$ & $52.52 \%$ \\
\hline Intensity (hl) & 786,122 & $1,281,378$ \\
\hline
\end{tabular}

${ }^{*} p<0.10 ;{ }^{* *} p<0.05 ;{ }^{* * *} p<0.01$

Source: Own elaboration based on Euromonitor International, http://www.euromonitor.com/passport, last access July 2015 and on Organisation for Economic Co-operation and Development (OECD), Statistics section, http://stats.oecd.org/, last access, July 2015. 


\section{Discussion of the Beer Industry}

In brief, there are distinct differences in the exposure of the beer industry to the business cycle per country. Spanish consumers are the most affected with both a high exposure and intensity of exposure. Italian and U.S. consumers follow, albeit the latter exhibit lower responsiveness. However, the U.K. and German markets demonstrate markedly lower exposures and intensities, with beer sales to Germans appearing largely unresponsive to the business cycle or any other exogenous factor. Finally, French beer drinkers are exposed to the business cycle countercyclically due to the substitution effect of beer and wine. Our results are summarized in Table B8.

\section{Table B8}

Summary of results for beer sales

\begin{tabular}{lccc}
\hline & Exposure & Intensity, \% & Intensity, thousands hl \\
\hline Spain & $78 \%$ & 0.95 & 305 \\
United Kingdom & $39 \%$ & 0.57 & 248 \\
Germany & $27 \%$ & 0.06 & 49 \\
France & $56 \%$ & -0.43 & -75 \\
Italy & $56 \%$ & 0.90 & 147 \\
United States & $53 \%$ & 0.49 & 1,281 \\
\hline
\end{tabular}

Source: Own elaboration based on Euromonitor International, http://www.euromonitor.com/passport, last access July 2015 and on Organisation for Economic Co-operation and Development (OECD), Statistics section, http://stats.oecd.org/, last access, July 2015.

Further, our data show that Americans may behave conservatively over certain periods and delay adjusting their drinking habits. For instance, we note the delay in the recovery of beer sales in the United States following the recovery of the U.S. economy in 2009, which highlights the strenuous impact of the 2008 financial crisis on people's confidence. Three years earlier, the reverse trend was observed with GDP deteriorating but beer consumption continuing to rise. In other words, optimism turned to pessimism following the near collapse of the banking system. Overall, American consumers seem to be more sensitive to the forecasted business cycle than their European counterparts.

In the United Kingdom, Germany and France, the beer market is in decline as can be seen by examining the market peaks in each country. In Italy and Spain, beer sales peaked in 2007 and started decreasing from 2008 onwards, as consumers reacted to the worsening economic conditions. In the United States, sales continued to rise in 2008 as consumers were slow to adjust to the first signs of the crisis and remained confident throughout most of that year. In France and Germany, the beer markets experienced negative growth and any positive activity that can be observed over the period cannot be attributed to the economic cycle. For example, the 2006 rise in beer consumption in Germany can be attributed to the 2006 FIFA World Cup, which attracted millions of soccer fans to the country. Even though the business cycle marked positive growth in 2006, the rise in beer consumption can better be explained by the popularity of beer as an accompaniment to watching the games and the sports tourism wave that Germany experienced over that year. Further, the 2003 rise in beer sales in France can be attributed to the hot summer weather and not to the fluctuations in the business cycle, as the GDP rate remained stable both during that year and the prior year, and increased only marginally in the following year. 
The reasons for the decline vary per country and pertain to consumer characteristics. In the United Kingdom, the beer market demonstrates a considerable and significant exposure to the business cycle, despite the negative volume growth in beer sales. In fact, the value of beer sales follows a more stable trend. Industry volume decline can be attributed largely to changing consumer habits. The increasing use of price promotions that followed the introduction of the beer duty escalator, which were aimed at mitigating the burden on consumers, resulted in a blurring of the price bands within lager. At the same time, imported premium lager is gaining popularity among U.K. consumers, at the expense of domestic standard lager. In view of these observations, the trade press has reported the beginnings of a premiumization trend, whereby U.K. consumers are becoming more discerning and favoring quality over quantity; thus, negative volume growth is observed. This behavior is reminiscent of that of French consumers, albeit to a much lesser extent.

In France, consumers are thought to follow a superpremiumization trend with a "drink less, drink better" attitude. The strong preference of French consumers for premium beers was maintained and reinforced despite higher excise duties over recent years, which only resulted in a reduction in volume but not a shift to a less expensive beer category. Further, beer consumption by the French is largely vulnerable to the threat from substitutes, such as spirits and more especially wine, due to the low switching costs and consumption patterns of the French. Superpremiumization and product substitution in France account for the poor exposure of the beer industry to the business cycle, as well as the lack of significance in explaining beer consumption from the GDP growth rate.

Finally, in Germany, beer market decline is not due to the premiumization trend, but sociodemographic change and growing health awareness. Germans are becoming increasingly health conscious and therefore are moderating their consumption of beer. In addition, among the younger generation, there is an increasing substitution effect from beer to other beverages. Increased health consciousness and product substitution have led to market stagnation and account for the very low exposure of the beer industry to the business cycle.

Our analysis considers volume instead of value, which filters the effect of price, category segmentation and distribution channels. In considering the distribution channels through which beer is sold, value matters since off-trade prices are lower than on-trade prices. Having filtered the effect of prices, we can further explore the differences in the weights of each distribution channel per country. Distribution channels matter in our analysis since fluctuations of on-trade sales are more exposed to transient industry effects. Off-trade channels exhibit lower exposures and are sometimes countercyclical.

We notice a general trend, especially within the context of the economic crisis, of the balance between on-trade and off-trade sales of beer to shift gradually in favor of the off-trade channel. But for some countries this effect is more reinforced to the point that off-trade sales channels dominate on-trade. For Spain and the United Kingdom, sales through on-trade channels still dominate. In 2013, the off-trade channels accounted for 43.3\% of beer sales in Spain and 47.7\% in the United Kingdom, less than half of total volume sales. However, there are different trends in the two countries. Whereas off-trade sales in Spain are enjoying a continuous rise as Spaniards increasingly enjoy beers outside restaurants or pubs, the proportion of off-trade vs. on-trade volume sales in the United Kingdom remained steady even throughout the financial crisis. This indicates that U.K. consumers did not change their tradition of going to the pub after work or on the weekend. The trend changes when we look at the proportion of the distribution channels in the other countries. In 2013, the off-trade channels accounted for $63.5 \%$ of beer sales in Italy, 64.2\% in Germany, 74.9\% in the United States and an impressive 75.5\% in France. Together with 
the increased frugality brought about by the economic crisis, the tradition of drinking beer in pubs seems to be fading away in these countries.

\section{The Automotive Industry}

Trade press reports suggest that growth patterns in the automotive market tend to mirror economic growth. We examine the relationship between car sales and the business cycle using the same method as before. Our choice of indicator for the level of industry activity is the change in new passenger car registrations, both domestic manufacturing and imported. Passenger cars are defined as motor vehicles with at least four wheels, used for the transport of passengers, with no more than eight seats in addition to the driver's seat. This description distinguishes between passenger cars and the broader group of light commercial vehicles, heavy trucks, buses and coaches, whose use is mostly professional rather than private. Since we are interested in household reactions with regard to the business cycle, we focus our analysis on passenger cars.

In Europe, the automotive industry accounts for 10.3\% of EU manufacturing employment. Germany, Italy, France, the United Kingdom and Spain are the "big five" countries with the strongest automotive sectors within the EU. For the purposes of our analysis, we look more closely at the big five EU manufacturers, as well as the United States and Japan. The data are obtained from the European Automobile Manufacturers Association (ACEA), the International Road Federation (IRF), Eurostat and national statistics.

We first analyze each country separately and then attempt to infer general observations from our results. We consider the time period from 1985 to 2013. We perform linear regressions of the rate of change in new passenger car registrations on the rate of growth of GDP. Since our data represent a time series that raises concerns for heteroskedasticity and autocorrelation of standard errors, we also apply the Newey-West method for obtaining robust standard errors for the OLS estimates (Hamilton, 2004). Finally, we caution readers that, in this section, the graphs depicting the growth rates of our two variables of interest have a different scale for each variable due to the fact that car sales fluctuate much more than the economy.

We compute, as before, measures of exposure and intensity of exposure. We report these results for both the benchmark model and the model with controls for government intervention, which are in the form of dummy variables that capture the exogenous shock for that year. A government incentive program is a formal scheme used to promote or encourage specific actions or behavior by a specific group of people during a defined period of time. For example, a scrappage program is a government budget program to promote the replacement of old vehicles with modern vehicles. Scrappage programs generally have the dual aim of stimulating the automobile industry and removing inefficient, high-emissions vehicles from the road. During the global recession that began in 2008, many countries introduced large-scale scrappage programs as an economic stimulus to increase market demand in the industrial sector, including the automotive sector. We control for these incentive programs both in terms of their effect during implementation, as well as their effects before and after they come into action. In this way, we can also discuss the net effect of government incentive schemes in the automotive industry per country.

\section{i. SPAIN}

The Spanish car market is among the largest in Europe. In 2009, LLAMA, the Spanish automotive industry, generated 3.5\% of Spain's GDP and provided employment to about 9\% of the working population. But in 2009 car production decreased, following a decade-long trend that started when a government policy was abandoned. The result was the loss of all car brands and 
manufacturers, which are now either closed or in the hands of foreign companies. Sociedad Española de Automóviles de Turismo (SEAT), which now operates as a subsidiary of the Volkswagen Group, is the sole active Spanish brand with a mass production potential and the ability to develop its own models in-house. Many foreign car and truck makers - such as Volkswagen, Nissan, Daimler AG, Ford, Renault, Opel, PSA Peugeot Citroën and Iveco - as well as suppliers have facilities and plants in Spain developing and producing vehicles and components, not only for the needs of the internal market but also for exportation purposes.

In 2008, the Spanish automotive market hit bottom with a $28 \%$ decrease in car sales, following severe economic contraction. In later years, the negative growth in sales continued but at more moderate levels, partly due to a government stimulus plan that lasted from January 2009 to October 2010. Further, throughout 2013 the Spanish government offered a series of car incentives in another attempt to boost sales as the economy struggled to emerge from recession. Figure C1 depicts the volume of new passenger car registrations in Spain. Figure C2 juxtaposes the growth rates of our two variables of interest, albeit at different scales due to the fact that car sales fluctuate much more than the economy.

\section{Figure $\mathrm{C} 1$}

Automotive market in Spain, 1982-2013

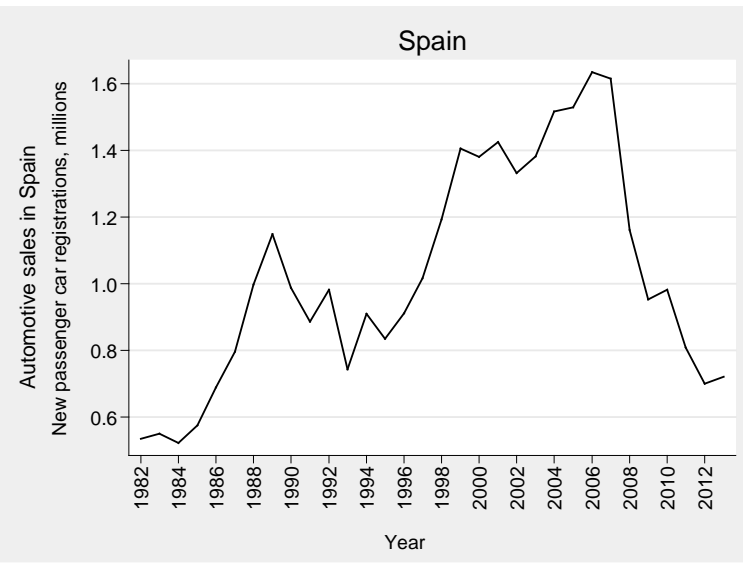

\section{Figure C2}

Spain, \% GDP and \% car sales

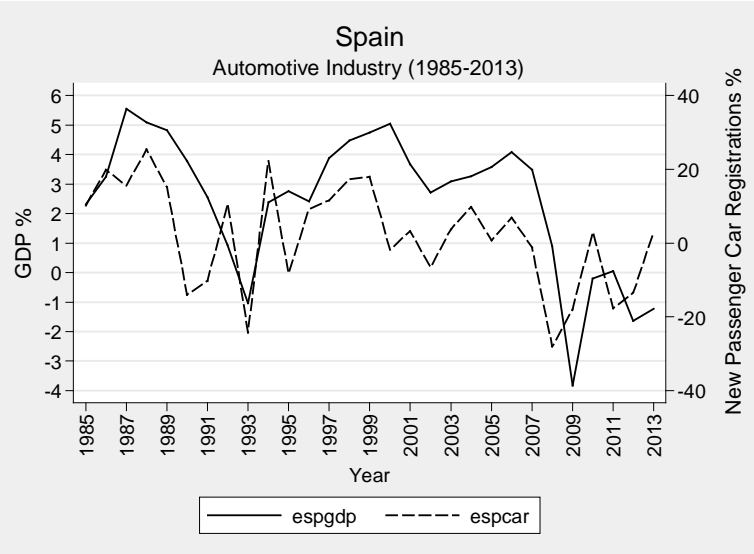

Source: Own elaboration based on the Passport database of Euromonitor International is http://www.euromonitor.com/passport, last access July 2015 and on Organisation for Economic Co-operation and Development (OECD), Statistics section, http://stats.oecd.org/, last access, July 2015.

In our analysis, we control for government intervention in 2009, 2010 and 2013. In addition, we control for the anticipation effect as well as the aftermath of the 2009/10 government scheme by introducing dummies for the years 2008 and 2011. Our results are shown in Table C1. In the final model (Model 4), the exposure of the Spanish automotive sector to the business cycle is 55\%, and its intensity is $4.2 \%$, with a corresponding volume of more than 30,000 car sales. The results resemble those of Ariño et al. (2008), who found exposure of 45\% and intensity of 5.5\%.

Model 3 estimates the net effect of the government scheme. The introduction of the incentive scheme in 2009 was overshadowed by the anticipation effect of the preceding year. In addition, the completion of the scheme was met with a decrease in car sales that appears significant from both statistical and economic perspectives. Hence, the net effect of the 2009/10 government incentive scheme, estimated by adding up the positive contributions of the slope coefficients during the years that the scheme ran (2009 and 2010) and subtracting the anticipation and postscheme effects (years 2008 and 2011) is a negative impact of 29\%. Government incentives 
tend to affect the timing of purchasing decisions when the size of the investment and hence the potential savings are considerable: people refrain from purchasing a car prior to the incentive scheme and car sales drop sharply as the incentives end. Our data indicate that, in the case of Spain, the benefit to the car industry may be short-term rather than long-term.

\section{Table C1}

OLS regression of the rate of change in passenger car sales, Spain, 1985-2013

\begin{tabular}{|c|c|c|c|c|}
\hline Variable & $\begin{array}{c}\text { Model 1: } \\
\text { Benchmark }\end{array}$ & $\begin{array}{l}\text { Model 2: } \\
\text { Incentives }\end{array}$ & $\begin{array}{l}\text { Model 3: } \\
\text { Net effect }\end{array}$ & $\begin{array}{l}\text { Model 4: } \\
\text { Final }\end{array}$ \\
\hline GDP growth rate & $\begin{array}{c}3.711^{\star \star \star} \\
(4.68)\end{array}$ & $\begin{array}{c}5.091^{\star \star *} \\
(4.43)\end{array}$ & $\begin{array}{c}3.409 * \star \\
(2.70)\end{array}$ & $\begin{array}{c}4.178^{\star \star \star} \\
(3.37)\end{array}$ \\
\hline Year 2008 & & & $\begin{array}{c}-25.96^{\star \star \star} \\
(-6.82)\end{array}$ & $\begin{array}{c}-23.71^{\star \star *} \\
(-6.09)\end{array}$ \\
\hline Year 2009 & & $\begin{array}{c}13.623 \\
(1.59)\end{array}$ & $\begin{array}{l}0.295 \\
(0.03)\end{array}$ & $\begin{array}{l}6.169 \\
(0.67)\end{array}$ \\
\hline Year 2010 & & $\begin{array}{c}19.152^{\star \star \star} \\
(3.44)\end{array}$ & $\begin{array}{l}8.927^{*} \\
(1.80)\end{array}$ & $\begin{array}{c}12.01^{\star *} \\
(2.39)\end{array}$ \\
\hline Year 2011 & & & $\begin{array}{c}-12.70^{\star \star} \\
(-2.71)\end{array}$ & $\begin{array}{l}-9.816^{*} \\
(-2.06)\end{array}$ \\
\hline Year 2013 & & $\begin{array}{c}21.386^{\star \star \star} \\
(3.73)\end{array}$ & & $\begin{array}{c}16.312^{* *} \\
(2.65)\end{array}$ \\
\hline$R^{2}$ (exposure) & $36.04 \%$ & $45.27 \%$ & $51.25 \%$ & $54.80 \%$ \\
\hline Intensity & 26,767 & 36,721 & 24,589 & 30,136 \\
\hline
\end{tabular}

${ }^{*} p<0.10 ;{ }^{* *} p<0.05 ;{ }^{* * *} p<0.01$

Source: Own elaboration based on the Passport database of Euromonitor International is http://www.euromonitor.com/passport, last access July 2015 and on Organisation for Economic Co-operation and Development (OECD), Statistics section, http://stats.oecd.org/, last access, July 2015.

\section{ii. UNITED KINGDOM}

The automotive industry in the United Kingdom is best known for premium and sports car marques including Aston Martin, Bentley, Jaguar, Land Rover, Lotus, McLaren and Rolls-Royce. Volume car manufacturers with a major presence in the United Kingdom include Honda, Nissan, Toyota and Vauxhall Motors (a subsidiary of Adam Opel AG, itself a wholly owned subsidiary of GM). The origins of the U.K. automotive industry date back to the late 19th century. By the 1950s the United Kingdom was the second largest manufacturer of cars in the world (after the United States) and the largest exporter. However, in subsequent decades the industry experienced considerably lower growth than competitor nations such as France, Germany and Japan and, by 2008, the United Kingdom was the 12th largest producer of cars measured by volume. Since the late 1980s many British car marques have been acquired by foreign companies including BMW (Mini and Rolls-Royce), Tata (Jaguar and Land Rover) and the Volkswagen Group (Bentley). Foreign companies also own the rights of many currently dormant marques, including Austin, Riley, Rover and Triumph.

U.K. new car sales peaked in 2003, following years of freely available credit and aggressive approaches by manufacturers. Figure C3 depicts the volume of new passenger car registrations in the United Kingdom. Figure C4 juxtaposes the growth rates of our two variables of interest, albeit at different scales due to the fact that car sales fluctuate much more than the economy. 
The U.K. automotive industry shrank markedly in 2008 as it was hit hard by the financial crisis. In 2009, as in several other countries, the U.K. government launched a scrappage incentive scheme in order to support the crisis-stricken industry. Its purpose was to encourage U.K. residents to purchase a new car and scrap an old one that they had owned for more than 12 months. The scheme came to an end in March 2010. The scrappage incentive scheme helped buyers to purchase new cars as the drop in sales was contained despite the continuous drop in GDP.

\section{Figure C3}

Automotive market in the United Kingdom, 1982-2013

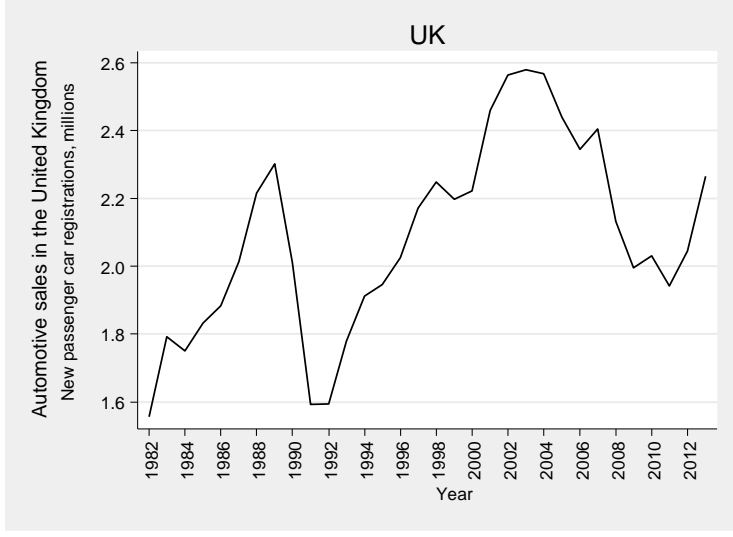

\section{Figure C4}

United Kingdom, \% GDP and \% car sales

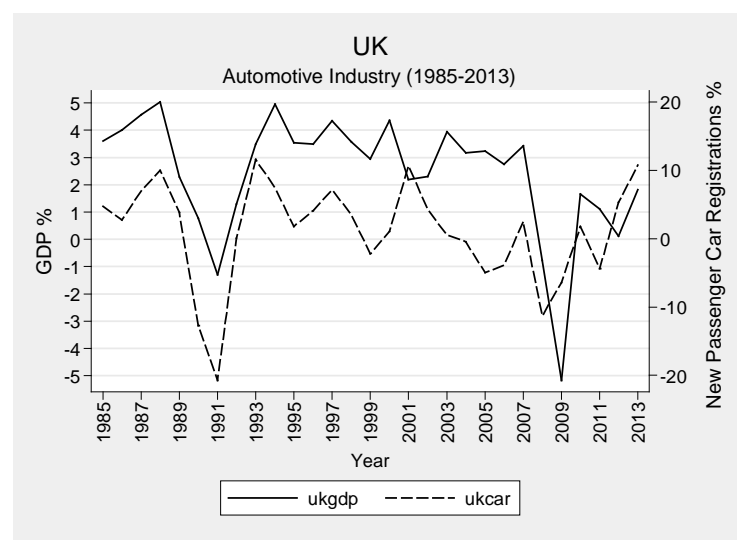

Source: Own elaboration based on the Passport database of Euromonitor International is http://www.euromonitor.com/passport, last access July 2015 and on Organisation for Economic Co-operation and Development (OECD), Statistics section, http://stats.oecd.org/, last access, July 2015.

We control for the 2009 scheme as well as its anticipation and posteffects. In the case of the United Kingdom, the effect of the incentive scheme in 2009 is stronger than that of the anticipation effect of the preceding year and the posteffect combined. The net effect is estimated at 14\% (Model 4); in other words, the car incentive was successful in generating a $6.4 \%$ increase in car sales.

In addition, we control for the 1991-92 recession, which hurt U.K. consumers in the form of high interest rates and unemployment. Though the movement of our key variables is in the same direction, nonetheless, the fluctuations in the rate of car sales are much more pronounced than those in GDP. Hence, we control for the years 1991 and 1992 using dummies. Our results, as depicted in Table C2, show that U.K. consumers reacted immediately to the economic crisis by limiting car purchases early on in 1991 and maintaining this low level throughout 1992.

We compute the final model by including only the controls with statistical significance, i.e., the years 1991 and 2009. Overall, the exposure of the U.K. automotive sector to the business cycle is $53 \%$, and its intensity is $2 \%$, with a corresponding volume of more than 47,000 car sales. The results are similar to those of Ariño et al. (2008), who found exposure of 55\% and intensity of 3.5\%. 


\section{Table C2}

OLS regressions of the rate of change in car sales, United Kingdom, 1985-2013

\begin{tabular}{|c|c|c|c|c|c|}
\hline Variable & $\begin{array}{c}\text { Model 1: } \\
\text { Benchmark }\end{array}$ & $\begin{array}{l}\text { Model 2: } \\
\text { 1991/92 }\end{array}$ & $\begin{array}{l}\text { Model 3: } \\
\text { GIS }\end{array}$ & $\begin{array}{l}\text { Model 4: } \\
\text { Net effect }\end{array}$ & $\begin{array}{l}\text { Model 5: } \\
\text { Final }\end{array}$ \\
\hline GDP growth rate & $\begin{array}{c}2.032^{\star \star *} \\
(2.91)\end{array}$ & $\begin{array}{c}1.565^{\star \star \star} \\
(3.19)\end{array}$ & $\begin{array}{c}2.887^{\star \star \star *} \\
(3.40)\end{array}$ & $\begin{array}{c}2.788^{\star *} \\
(2.42)\end{array}$ & $\begin{array}{c}2.099 * * \\
(2.50)\end{array}$ \\
\hline Year 1991 & & $\begin{array}{c}-16.64^{\star \star \star} \\
(-6.42)\end{array}$ & & & $\begin{array}{c}-14.29^{\star \star \star} \\
(-3.42)\end{array}$ \\
\hline Year 1992 & & $\begin{array}{l}0.132 \\
(0.09)\end{array}$ & & & \\
\hline Year 2008 & & & & $\begin{array}{l}-3.052 \\
(-0.60)\end{array}$ & \\
\hline Year 2009 & & & $\begin{array}{l}14.89^{*} \\
(2.01)\end{array}$ & $\begin{array}{c}14.123 \\
(1.40)\end{array}$ & $\begin{array}{l}8.170 \\
(1.10)\end{array}$ \\
\hline Year 2010 & & & & $\begin{array}{l}3.292 \\
(1.37)\end{array}$ & \\
\hline$R^{2}$ (exposure) & $35.54 \%$ & $51.03 \%$ & $43.15 \%$ & $44.41 \%$ & $53.00 \%$ \\
\hline Intensity (cars) & 46,015 & 35,439 & 65,376 & 63,134 & 47,532 \\
\hline
\end{tabular}

${ }^{*} p<0.10 ;{ }^{* *} p<0.05 ;{ }^{* * *} p<0.01$

Source: Own elaboration based on the Passport database of Euromonitor International is http://www.euromonitor.com/passport, last access July 2015 and on Organisation for Economic Co-operation and Development (OECD), Statistics section, http://stats.oecd.org/, last access, July 2015.

\section{iii. GERMANY}

Germany is considered to be the birthplace of the automobile since Karl Benz and Nikolaus Otto independently developed four-stroke internal combustion engines in the late 1870s, with Benz fitting his design to a coach in 1887, which led to the modern-day motorcar. Alongside the United States, China and Japan, Germany is one of the top four automobile manufacturers in the world. The Volkswagen Group is one of the three biggest automotive companies of the world (along with Toyota and General Motors).

Currently, five German companies and seven marques dominate the automotive industry in the country: Volkswagen AG (and subsidiaries Audi and Porsche), BMW AG, Daimler AG, Adam Opel AG and Ford-Werke GmbH. Nearly six million vehicles are produced in Germany each year, and approximately 5.5 million are produced overseas by German brands. German-designed cars have won multiple times in the European Car of the Year, the International Car of the Year and the World Car of the Year annual awards. Two cars (the Volkswagen Beetle and Porsche 911) took fourth and fifth places in the Car of the Century award.

The 2008 economic crisis affected German car sales deeply to the extent that the government intervened with a scheme in 2009. Whereas car sales in Germany exploded in 2009 by more than $23 \%$, fuelled by the implementation of government incentives, the market collapsed in 2010 by a swing of an equal magnitude in the opposite direction, following the completion of the government schemes. Figure $\mathrm{C} 5$ depicts the volume of new passenger car registrations in Germany, and Figure C6 presents the evolution of the car sales and GDP growth rates, at different scales. 


\section{Figure C5}

Automotive market in Germany, 1982-2013

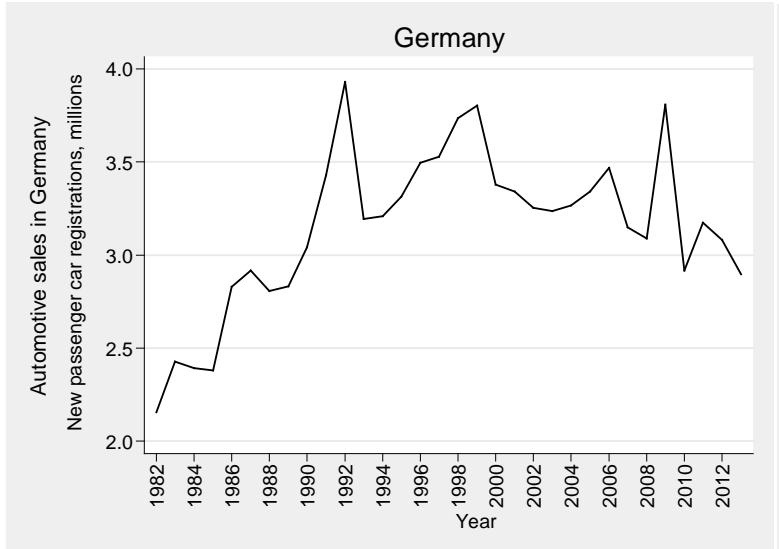

\section{Figure C6}

Germany, \% GDP and \% car sales

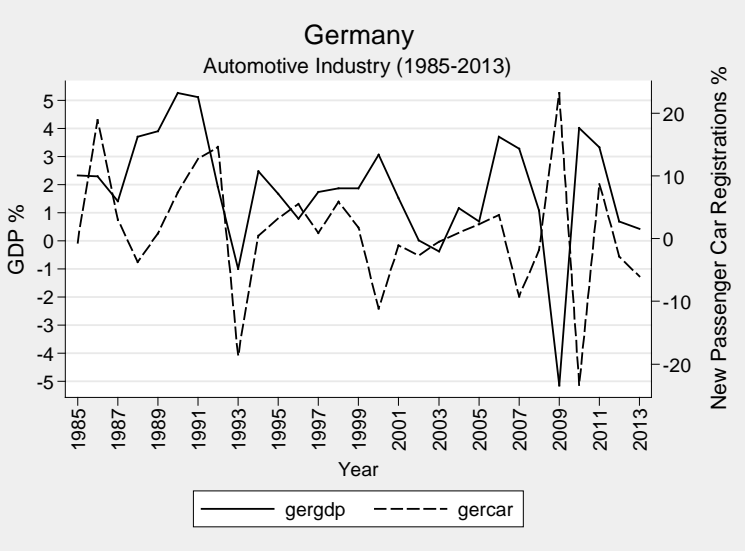

Source: Own elaboration based on the Passport database of Euromonitor International is http://www.euromonitor.com/passport, last access July 2015 and on Organisation for Economic Co-operation and Development (OECD), Statistics section, http://stats.oecd.org/, last access, July 2015.

We control for the anticipation of the scheme as well as its effect after completion. In addition, we control for the severe recession in 1993, which constrained German consumers and had an amplified effect on car sales. Our results are shown in Table C3. In the final model (Model 5), the exposure of the German automotive sector to the business cycle is 59\%, and its intensity is $1.1 \%$, with a corresponding volume of roughly 31,000 car sales. The results are very similar to prior analysis (Ariño et al., 2008), where exposure of the German automotive industry to the business cycle was 50\%, with intensity $2 \%$. In other words, almost half of the variation in car sales in Germany can be explained by fluctuations in the business cycle. Further, the net effect of the government scheme on actual car sales is estimated at a low 5.7\% (Model 4).

\section{Table C3}

OLS regressions of the rate of change in car sales, Germany, 1985-2013

\begin{tabular}{|c|c|c|c|c|c|}
\hline Variable & $\begin{array}{c}\text { Model 1: } \\
\text { Benchmark }\end{array}$ & $\begin{array}{c}\text { Model 2: } \\
1993\end{array}$ & $\begin{array}{l}\text { Model 3: } \\
\text { GIS 2009 }\end{array}$ & $\begin{array}{l}\text { Model 4: } \\
\text { Net effect }\end{array}$ & $\begin{array}{l}\text { Model 5: } \\
\text { Final }\end{array}$ \\
\hline GDP growth rate & $\begin{array}{l}-0.733 \\
(-0.53)\end{array}$ & $\begin{array}{l}-1.321 \\
(-1.14)\end{array}$ & $\begin{array}{l}-1.100 \\
(0.87)\end{array}$ & $\begin{array}{l}1.910^{*} \\
(1.92)\end{array}$ & $\begin{array}{l}1.053 \\
(1.34)\end{array}$ \\
\hline Year 1993 & & $\begin{array}{c}-24.41^{\star \star \star} \\
(-7.16)\end{array}$ & & & $\begin{array}{c}-17.53^{\star \star \star} \\
(-7.78)\end{array}$ \\
\hline Year 2008 & & & & $\begin{array}{l}-1.375 \\
(-0.76)\end{array}$ & $\begin{array}{l}-2.86^{\star \star} \\
(-2.14)\end{array}$ \\
\hline Year 2009 & & & $\begin{array}{c}30.81 \text { *** } \\
(3.51)\end{array}$ & $\begin{array}{c}35.58^{\star * *} \\
(4.88)\end{array}$ & $\begin{array}{c}28.76^{\star \star \star *} \\
(5.49)\end{array}$ \\
\hline Year 2010 & & & & $\begin{array}{c}-28.52^{\star \star \star} \\
(-11.41)\end{array}$ & $\begin{array}{c}-27.50^{\star \star \star} \\
(-11.04)\end{array}$ \\
\hline$R^{2}$ (exposure) & $2.37 \%$ & $22.50 \%$ & $22.06 \%$ & $49.91 \%$ & $59.32 \%$ \\
\hline Intensity (cars) & $-21,236$ & $-38,272$ & $-31,869$ & 55,337 & 30,508 \\
\hline
\end{tabular}

${ }^{*} p<0.10 ;{ }^{* *} p<0.05 ;{ }^{* * *} p<0.01$

Source: Own elaboration based on the Passport database of Euromonitor International is http://www.euromonitor.com/passport, last access July 2015 and on Organisation for Economic Co-operation and Development (OECD), Statistics section, http://stats.oecd.org/, last access, July 2015. 


\section{iv. FRANCE}

France is home to two major automobile-making companies - PSA Peugeot Citroën (owner of the Peugeot and Citroën marques) and Renault SA (owner of the Renault marque and of Dacia of Romania, and Renault Samsung Motors of South Korea). France was a pioneer in the automotive industry and French-designed cars have won the European Car of the Year and World Car of the Year awards numerous times. For instance, the Citroën DS took third place in the Car of the Century award and has been named the most beautiful car of all time by Classic \& Sports Car magazine.

On November 24, 2008, French president Nicolas Sarkozy agreed to support the crisis-stricken automobile industry in France and, in 2009, the French government introduced incentives for the car industry, spurring sales by 12.3\%. Figure C7 depicts the volume of new passenger car registrations in France. Figure C8 juxtaposes the growth rates of our two variables of interest, albeit at different scales due to the fact that car sales fluctuate much more than the economy. The plunge in car sales in 1993 and 1997 is noteworthy.

\section{Figure C7}

Automotive market in France, 1982-2013

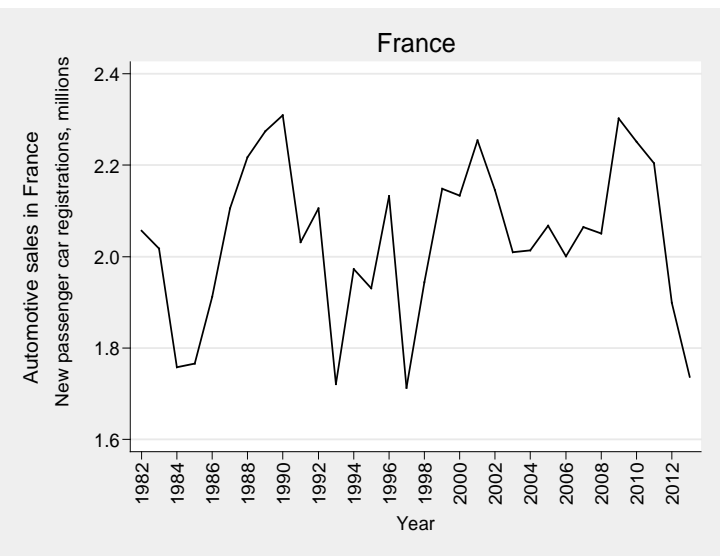

\section{Figure C8}

France, $\%$ GDP and $\%$ car sales

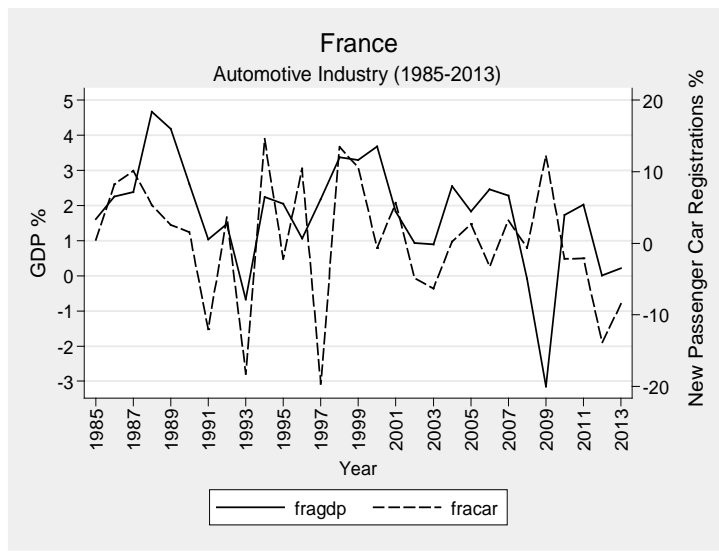

Source: Own elaboration based on the Passport database of Euromonitor International is http://www.euromonitor.com/passport, last access July 2015 and on Organisation for Economic Co-operation and Development (OECD), Statistics section, http://stats.oecd.org/, last access, July 2015.

The dramatic fall in demand for cars in 1993 and 1997 may be attributed to the completion of the government incentive schemes. In fact, the French government introduced car scrapping programs in 1994, 1996 and 2009 to boost demand for cars in the face of unfavorable economic conditions (OECD, 2010). In our analysis, we control for these interventions and calculate their net effects; our results are shown in Table C4. The net effects of the 1994 and 1996 government schemes were negative, with the former resulting in an overall fall in sales of $6 \%$ and the latter $14 \%$. With regard to the 2009 scheme, the net effect of the three-year period (2008 to 2010) is positive at $41 \%$.

In our final model, the exposure of the French automotive sector to the business cycle for the period 1985 to 2013 is 74\%, and its intensity is close to $4 \%$ or 69,000 cars. The intensity is similar to the 4.5\% found by Ariño et al. (2008), where the exposure, controlled for the effects of all government incentive schemes, is much higher than $30 \%$. The dramatic change in exposure that results from accounting for government interventions is testament to the amplitude of the effect on French consumers. 


\section{Table C4}

OLS regressions of the rate of change in car sales, France, 1985-2013

\begin{tabular}{|c|c|c|c|c|c|c|}
\hline Variable & $\begin{array}{c}\text { Model 1: } \\
\text { Benchmark }\end{array}$ & $\begin{array}{l}\text { Model 2: } \\
\text { GIS }\end{array}$ & $\begin{array}{l}\text { Model 3: } \\
\text { Net effect } \\
\text { GI } 1994\end{array}$ & $\begin{array}{l}\text { Model 4: } \\
\text { Net effect } \\
\text { GI } 1996\end{array}$ & $\begin{array}{l}\text { Model 5: } \\
\text { Net effect } \\
\text { GI } 2009\end{array}$ & $\begin{array}{l}\text { Model 6: } \\
\text { Final }\end{array}$ \\
\hline GDP growth rate & $\begin{array}{l}1.483 \\
(0.90)\end{array}$ & $\begin{array}{c}3.964^{\star \star \star} \\
(3.96)\end{array}$ & $\begin{array}{l}0.791 \\
(0.51)\end{array}$ & $\begin{array}{l}1.742 \\
(0.96)\end{array}$ & $\begin{array}{c}4.137^{\star \star * *} \\
(3.68)\end{array}$ & $\begin{array}{c}3.964^{\star \star \star} \\
(3.31)\end{array}$ \\
\hline Year 1993 & & & $\begin{array}{c}-16.92^{\star * *} \\
(-3.54)\end{array}$ & & & $\begin{array}{c}-7.711 \text { ** } \\
(-2.33)\end{array}$ \\
\hline Year 1994 & & $\begin{array}{c}14.50 \text { *** } \\
(9.98)\end{array}$ & $\begin{array}{c}13.66^{\star \star \star} \\
(8.52)\end{array}$ & & & $\begin{array}{c}13.62^{\star \star \star} \\
(10.12)\end{array}$ \\
\hline Year 1995 & & & $\begin{array}{l}-2.95^{\star} \\
(-1.82)\end{array}$ & $\begin{array}{l}-3.49^{\star *} \\
(-2.46)\end{array}$ & & $\begin{array}{c}-2.361^{*} \\
(-1.83)\end{array}$ \\
\hline Year 1996 & & $\begin{array}{c}15.00 * \star * \\
(9.42)\end{array}$ & & $\begin{array}{c}10.81^{\star * *} \\
(4.18)\end{array}$ & & $\begin{array}{c}14.11^{\star \star \star} \\
(8.75)\end{array}$ \\
\hline Year 1997 & & & & $\begin{array}{c}-21.24^{\star \star *} \\
(-15.54)\end{array}$ & & $\begin{array}{c}-20.41^{\star \star *} \\
(-15.42)\end{array}$ \\
\hline Year 2008 & & & & & $\begin{array}{c}7.96^{\star \star *} \\
(2.84)\end{array}$ & $\begin{array}{c}7.535^{\star \star} \\
(2.81)\end{array}$ \\
\hline Year 2009 & & $\begin{array}{c}33.56^{\star \star *} \\
(6.48)\end{array}$ & & & $\begin{array}{c}33.63^{* * *} \\
(5.64)\end{array}$ & $\begin{array}{c}32.67^{\star \star \star} \\
(5.30)\end{array}$ \\
\hline Year 2010 & & & & & $\begin{array}{l}-1.023 \\
(-0.63)\end{array}$ & \\
\hline$R^{2}$ (exposure) & $6.61 \%$ & $51.37 \%$ & $26.50 \%$ & $31.88 \%$ & $36.02 \%$ & $74.39 \%$ \\
\hline Intensity (cars) & 25,766 & 68,871 & 13,743 & 30,266 & 71,876 & 68,871 \\
\hline
\end{tabular}

${ }^{*} p<0.10 ;{ }^{* *} p<0.05 ;{ }^{* * *} p<0.01$

Source: Own elaboration based on the Passport database of Euromonitor International is http://www.euromonitor.com/passport, last access July 2015 and on Organisation for Economic Co-operation and Development (OECD), Statistics section, http://stats.oecd.org/, last access, July 2015.

\section{v. ITALY}

Italy's automotive industry is best known for its automobile designs and small city cars, sports cars and supercars. The industry is dominated by one firm, Fiat, which has large investments outside Italy including a 100\% stake in the American automaker Chrysler (now known as Fiat Chrysler Automobiles, FCA) as of January 2014. FCA comprises brands such as Alfa Romeo, Maserati and Ferrari. Despite recent troubles, Italy remains one of the significant players in car design and technology. The Italian automotive market declined on average over the period 1985 to 2013 as sales fell $0.21 \%$. Car sales appear sensitive to economic fluctuations, to the extent of closely mimicking the business cycle. Figure C9 depicts the volume of new passenger car registrations in Italy and Figure C10 shows the growth rates. There are two notable exceptions to this comovement. First, in 1997, Italy introduced an incentive plan, financed by the government and the industry, under which car owners would receive price discounts on new cars when they traded in cars more than 10 years old. As a result, car sales soared by 38.8\%. Similarly, in 2009, following the economic crisis, the Italian government used incentives to encourage sales of new cars; as a result, the Italian automotive market returned to $0 \%$ growth, a great improvement in view of the dramatic fall in 2008 of 13.3\%. 


\section{Figure C9}

Automotive market, Italy, 1982-2013

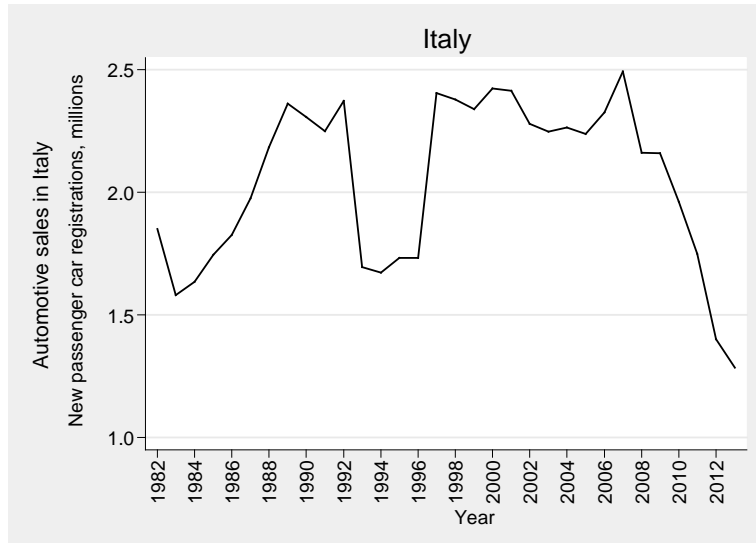

Figure $\mathrm{C} 10$

Italy, \% GDP and \% car sales, 1985-2013

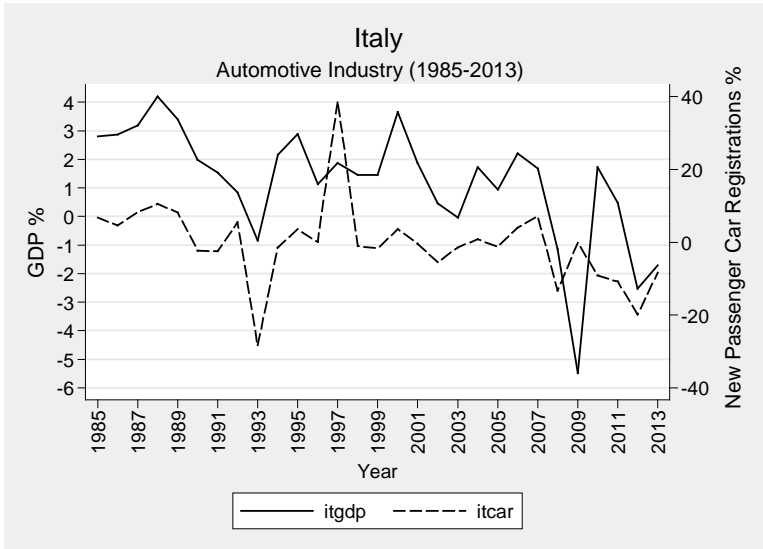

Source: Own elaboration based on the Passport database of Euromonitor International is http://www.euromonitor.com/passport, last access July 2015 and on Organisation for Economic Co-operation and Development (OECD), Statistics section, http://stats.oecd.org/, last access, July 2015.

Upon controlling for government intervention in these two cases, the exposure jumps to 83\%, and the intensity is $4.5 \%$. The strength of this relationship for the Italian market is notable. Our results imply that $80.4 \%$ of the variations in car sales to Italian consumers can be explained by fluctuations in the business cycle. This result differs from the $20 \%$ exposure found by Ariño et al. (2008) and the change may be attributed to controlling for government interventions. This attests to the sensitivity of Italian consumers to government incentives. For the three-year period (prior to, during and after the scheme), the net effects of the 1997 and 2009 government incentives are positive at $40 \%$ and $20 \%$ respectively. This finding merits caution as the impact of state aid may well span more than the three-year period we are considering. 


\section{Table C5}

OLS regressions of the rate of change in car sales, Italy, 1985-2013

\begin{tabular}{|c|c|c|c|c|c|}
\hline Variable & $\begin{array}{c}\text { Model 1: } \\
\text { Benchmark }\end{array}$ & $\begin{array}{l}\text { Model 2: } \\
\text { GIS }\end{array}$ & $\begin{array}{c}\text { Model 3: } \\
\text { Net effect 1997 }\end{array}$ & $\begin{array}{c}\text { Model 4: } \\
\text { Net effect } 2009\end{array}$ & $\begin{array}{l}\text { Model 5: } \\
\text { Final }\end{array}$ \\
\hline GDP growth rate & $\begin{array}{c}2.789^{\star *} \\
(2.20)\end{array}$ & $\begin{array}{l}4.412^{\star \star \star} \\
(5.97)\end{array}$ & $\begin{array}{l}2.567^{*} \\
(1.96)\end{array}$ & $\begin{array}{l}4.639 \star \star \star \\
(4.92)\end{array}$ & $\begin{array}{l}4.453^{\star \star \star} \\
(5.89)\end{array}$ \\
\hline Year 1996 & & & $\begin{array}{l}1.779 \\
(1.15)\end{array}$ & & \\
\hline Year 1997 & & $\begin{array}{l}38.44^{\star \star *} \\
(43.41)\end{array}$ & $\begin{array}{l}38.64^{\star \star *} \\
(34.46)\end{array}$ & & $\begin{array}{l}38.08^{\star * *} \\
(44.60)\end{array}$ \\
\hline Year 1998 & & & $\begin{array}{l}-0.103 \\
(-0.08)\end{array}$ & & \\
\hline Year 2008 & & & & $\begin{array}{l}-1.510 \\
(-0.44)\end{array}$ & \\
\hline Year 2009 & & $\begin{array}{c}32.05^{\star \star \star} \\
(5.47)\end{array}$ & & $\begin{array}{c}31.81^{\star \star *} \\
(4.43)\end{array}$ & $\begin{array}{l}31.99 * \star \star \\
(5.32)\end{array}$ \\
\hline Year 2010 & & & & $\begin{array}{c}-10.74^{\star \star \star} \\
(-5.72)\end{array}$ & $\begin{array}{c}-9.214^{\star \star \star} \\
(-10.13)\end{array}$ \\
\hline$R^{2}$ (exposure) & $24.80 \%$ & $80.43 \%$ & $64.16 \%$ & $44.52 \%$ & $82.67 \%$ \\
\hline Intensity (cars) & 35,841 & 56,699 & 32,989 & 59,616 & 57,226 \\
\hline
\end{tabular}

${ }^{*} p<0.10 ;{ }^{* *} p<0.05 ;{ }^{* * *} p<0.01$

Source: Own elaboration based on the Passport database of Euromonitor International is http://www.euromonitor.com/passport, last access July 2015 and on Organisation for Economic Co-operation and Development (OECD), Statistics section, http://stats.oecd.org/, last access, July 2015.

\section{vi. UNITED STATES}

The United States has one of the largest automotive markets in the world and is home to 13 auto manufacturers. General Motors, Ford, and Chrysler, often referred to as the "Big Three," are the largest automakers in the United States. Honda opened its first U.S. plant in 1982; since then, almost every major European, Japanese, and Korean automaker has produced vehicles at one or more U.S. assembly plants. In addition to Honda and the Big Three U.S. auto companies, Toyota, Nissan, Hyundai-Kia, BMW, Mercedes-Benz, Mazda, Mitsubishi, and Subaru all have U.S. manufacturing facilities. In May 2011, Volkswagen opened a new U.S. plant, bringing the manufacturer count to 13. In addition, many manufacturers also have engine and transmission plants and conduct research and development, design, and testing in the United States. The automotive industry, including dealerships, accounts for approximately 3.5\% of U.S. GDP. Motor vehicles and parts manufacturers directly employed 786,000 people at the end of 2012.

Figure C11 depicts the volume of new passenger car registrations in the United States. Figure C12 juxtaposes the growth rates of our two variables of interest, albeit at different scales due to the fact that car sales fluctuate much more than the economy. Over the years, the U.S. government introduced scrappage programs to boost car sales. Throughout our period of study these schemes took place in 2001, 2005 and 2009 (OECD, 2010). 


\section{Figure C11}

Automotive market in the United States, 1982-2013

\section{Figure $\mathrm{C} 12$}

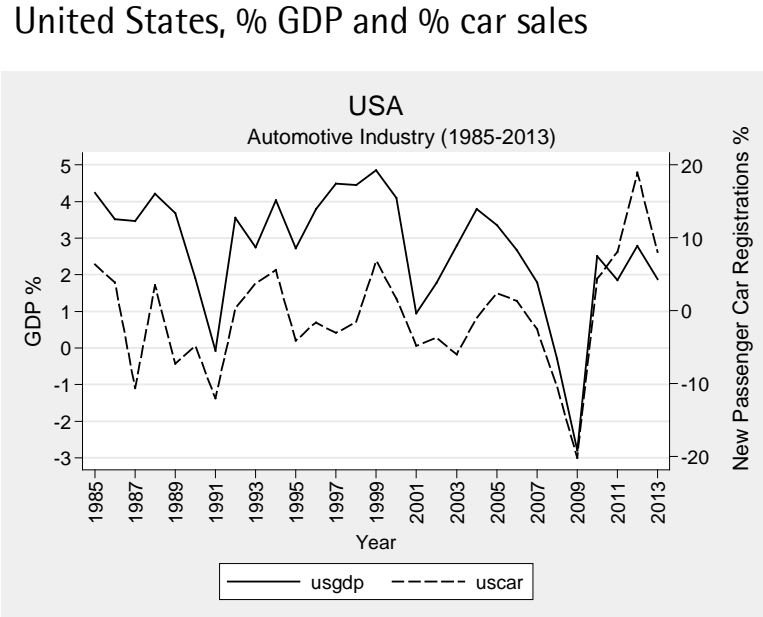

Source: Own elaboration based on the Passport database of Euromonitor International is http://www.euromonitor.com/passport, last access July 2015 and on Organisation for Economic Co-operation and Development (OECD), Statistics section, http://stats.oecd.org/, last access, July 2015.

The year 2006 saw the start of sector contraction, triggered by high oil prices. The contraction accelerated in 2008. In 2009, against the backdrop of the breakdown of the U.S. real estate market and the bankruptcy of Lehman Brothers, the financing terms for consumer durables deteriorated and the U.S. car market collapsed. At that point, the U.S. Congress came to the rescue and approved the Car Allowance Rebate System (CARS), a \$3 billion U.S. federal program that aimed to help U.S. citizens purchase a new, more fuel-efficient vehicle when trading in a less fuelefficient vehicle. The CARS program lasted only for that year as the budget was quickly exhausted. In addition, given the already existing trend of buying vehicles with higher fuel economy due to increased environmental sensitivity among consumers and the high gasoline prices of 2007 and 2008, the effect of the scheme was marginal. It did succeed, however, in containing the decline in car sales to similar levels as the decline in the economy, and in preventing the market from plunging further. A strengthening economy and improved consumer sentiment boosted car sales for the following two years, pushing growth into positive territory.

Controlling for government intervention in 2009, the exposure of the U.S. automotive sector to the business cycle for the period 1985 to 2013 is 36\%, and its intensity is $1.9 \%$, or 148,000 cars. Both exposure and intensity are below the estimates of Ariño et al. (2008), who found exposure to be $50 \%$ and intensity $2.8 \%$. The 2001 and 2005 schemes do not affect the relationship between the demand for cars and the business cycle. As for the 2009 scheme, its net effect over the threeyear period (2008 to 2010) is negative at $-13 \%$. 


\section{Table C6}

OLS regressions of the rate of change in car sales, United States, 1985-2013

\begin{tabular}{|c|c|c|c|c|}
\hline Variable & $\begin{array}{c}\text { Model 1: } \\
\text { Benchmark }\end{array}$ & $\begin{array}{l}\text { Model 2: } \\
\text { GIS }\end{array}$ & $\begin{array}{c}\text { Model 3: } \\
\text { Net effect 2009 }\end{array}$ & $\begin{array}{c}\text { Model } 4 \\
\text { Final }\end{array}$ \\
\hline GDP growth rate & $\begin{array}{c}2.526^{\star \star \star} \\
(4.51)\end{array}$ & $\begin{array}{l}1.775^{*} \\
(1.98)\end{array}$ & $\begin{array}{l}1.498 \\
(1.46)\end{array}$ & $\begin{array}{c}1.892^{\star \star} \\
(2.48)\end{array}$ \\
\hline Year 2001 & & $\begin{array}{l}-1.394 \\
(-0.55)\end{array}$ & & \\
\hline Year 2005 & & $\begin{array}{l}1.563 \\
(1.16)\end{array}$ & & \\
\hline Year 2008 & & & $\begin{array}{l}-5.756 \\
(-1.44)\end{array}$ & \\
\hline Year 2009 & & $\begin{array}{c}-10.10^{*} \\
(-1.78)\end{array}$ & $\begin{array}{c}-11.72^{\star} \\
(-1.80)\end{array}$ & $\begin{array}{c}-9.246^{\star} \\
(-1.94)\end{array}$ \\
\hline Year 2010 & & & $\begin{array}{c}4.883^{\star \star \star} \\
(3.06)\end{array}$ & $\begin{array}{c}5.261^{\star \star \star} \\
(3.81)\end{array}$ \\
\hline$R^{2}$ (exposure) & $30.86 \%$ & $34.45 \%$ & $37.34 \%$ & $35.83 \%$ \\
\hline Intensity (cars) & 197,579 & 138,837 & 117,171 & 147,988 \\
\hline
\end{tabular}

${ }^{*} p<0.10 ;{ }^{* *} p<0.05 ;{ }^{* * *} p<0.01$

Source: Own elaboration based on the Passport database of Euromonitor International is http://www.euromonitor.com/passport, last access July 2015 and on Organisation for Economic Co-operation and Development (OECD), Statistics section, http://stats.oecd.org/, last access, July 2015.

\section{vii. JAPAN}

The Japanese automotive industry is one of the most prominent and largest industries in the world. Japanese automakers Toyota, Nissan, and Honda, among many others, have long been considered the leaders at producing smaller, fuel-efficient cars. The automotive industry in Japan rapidly increased from the 1970s to the 1990s. In the 1980s and 1990s, Japan overtook the United States as the production leader with up to 13 million cars per year manufactured and significant exports. After a massive ramp-up by China in the 2000s and fluctuating U.S. output, Japan is the third largest automotive producer in the world with annual production of 9.9 million automobiles in 2012. Japanese investment helped grow the auto industry in many countries throughout the past few decades. The country is home to a number of companies that produce cars, construction vehicles, motorcycles, and engines. Japanese automotive manufacturers include Toyota, Honda, Nissan, Suzuki, Mazda, Mitsubishi, Subaru, Isuzu, Kawasaki and Yamaha. Cars designed in Japan have won the European Car of the Year, International Car of the Year, and World Car of the Year awards many times.

The Japanese auto industry has also suffered many setbacks. Figure C13 depicts the volume of new passenger car registrations in Japan and Figure C14 shows the growth rates. Three separate but related recalls of automobiles by Toyota Motor Corporation occurred at the end of 2009 and start of 2010, following reports that several vehicles experienced unintended acceleration. In response, on April 1, 2009, Japan became another of the countries to introduce a program targeted at reviving its automotive industry. Further, the 2011 earthquake off the Pacific coast of Tōhoku, the most powerful earthquake ever recorded to have hit Japan, had both a major social and economic impact. We control for this natural disaster using a dummy for the year. 


\section{Figure C13}

Automotive market in Japan, 1982-2013

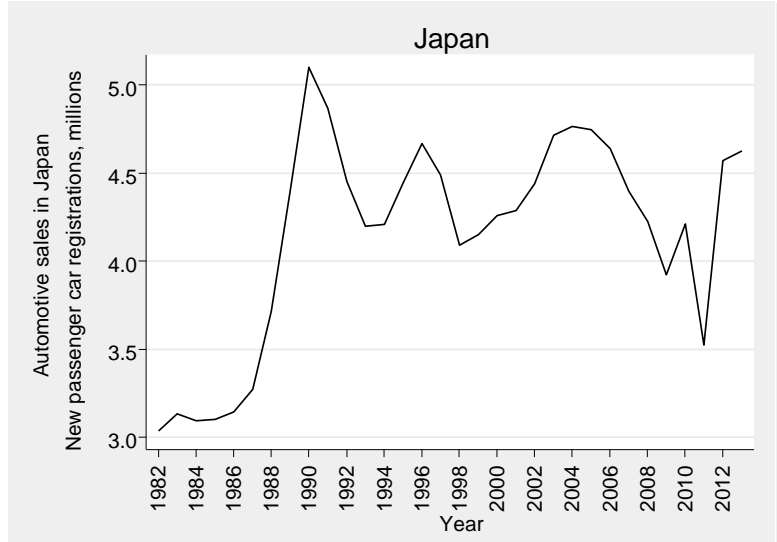

\section{Figure $\mathrm{C} 14$}

Japan, \% GDP and \% car sales

Source: Own elaboration based on the Passport database of Euromonitor International is http://www.euromonitor.com/passport, last access July 2015 and on Organisation for Economic Co-operation and Development (OECD), Statistics section, http://stats.oecd.org/, last access, July 2015.

Controlling for these two shocks, the exposure of the Japanese automotive sector to the business cycle for the period 1985 to 2013 is 39\%, and its intensity is 2\%, or 90,000 cars. The results are conservative compared with those of Ariño et al. (2008), who found exposure of 60\% and intensity of 2.5\%. Further, the impact of the 2009 government scheme is not statistically significant in our analysis; its net effect nonetheless is positive at 9\%. Our results are shown in Table C7.

\section{Table C7}

OLS regressions of the rate of change in car sales, Japan, 1985-2013

\begin{tabular}{|c|c|c|c|c|}
\hline Variable & $\begin{array}{c}\text { Model 1: } \\
\text { Benchmark }\end{array}$ & $\begin{array}{c}\text { Model 2: } \\
\text { Net effect 2009 }\end{array}$ & $\begin{array}{c}\text { Model 3: } \\
\text { Earthquake }\end{array}$ & $\begin{array}{l}\text { Model 4: } \\
\text { Final }\end{array}$ \\
\hline GDP growth rate & $\begin{array}{c}1.925^{\star \star \star} \\
(4.13)\end{array}$ & $\begin{array}{l}2.259 \star \star \star \\
(3.21)\end{array}$ & $\begin{array}{c}1.740 * \star \star \\
(4.12)\end{array}$ & $\begin{array}{c}1.946 * \star \star \\
(3.41)\end{array}$ \\
\hline Year 2008 & & $\begin{array}{l}1.112 \\
(0.38)\end{array}$ & & \\
\hline Year 2009 & & $\begin{array}{l}7.983 \\
(1.39)\end{array}$ & & $\begin{array}{l}5.057 \\
(1.10)\end{array}$ \\
\hline Year 2010 & & $\begin{array}{l}-0.472 \\
(-0.19)\end{array}$ & & \\
\hline Year 2011 & & & $\begin{array}{c}-14.43^{\star \star \star} \\
(-8.62)\end{array}$ & $\begin{array}{c}-13.72^{\star \star \star} \\
(-6.36)\end{array}$ \\
\hline $\mathrm{R}^{2}$ (exposure) & $29.92 \%$ & $31.68 \%$ & $38.21 \%$ & $38.93 \%$ \\
\hline Intensity (cars) & 89,062 & 104,515 & 80,503 & 90,034 \\
\hline
\end{tabular}

${ }^{*} p<0.10 ;{ }^{* *} p<0.05 ;{ }^{* * *} p<0.01$

Source: Own elaboration based on the Passport database of Euromonitor International is http://www.euromonitor.com/passport, last access July 2015 and on Organisation for Economic Co-operation and Development (OECD), Statistics section, http://stats.oecd.org/, last access, July 2015. 


\section{Discussion of the Automotive Industry}

In general, variations in car sales follow economic fluctuations as the correlations are consistently strong across countries and continents. The Italian and French automotive industries appear to be the most exposed to the business cycle, while the Spanish industry also demonstrates a high intensity of exposure. In other words, Italian, French and Spanish car sales are the most dependent on fluctuations in overall economic activity. The German and U.K. markets follow in terms of strength of exposure, while Japan and the United States are less exposed. Our results are summarized in Table C8.

Some distortions in automotive sales become apparent in periods of government intervention (incentive schemes to countercyclically boost the sales of cars). It is worth noting the dramatic change in exposure that results from accounting for these government schemes; the change in behavior regarding car purchases as a result of the incentive scheme attests to the importance that government actions have on consumers in the countries in our study, which temporarily outweighs the effect of the business cycle. Further, the net effect of the national incentive schemes varies by nation. Italy, the United Kingdom, Germany, France and Japan exhibit positive net effects as a result of the 2009 car incentives. Spain and the United States, however, have not benefited from these schemes. In any case, we caution that the measurement of the net effect considers only one year before and after the duration of the scheme; in reality, the effect may be spread out over a longer period. The findings allow us to be skeptical about the effectiveness of the government incentives in the long run.

\section{Table C8}

Automotive industry summary, 1985-2013

\begin{tabular}{lcccc}
\hline & Exposure & Intensity, \% & $\begin{array}{c}\text { Intensity, } \\
\text { thousands cars }\end{array}$ & Net effect of GIS, \% \\
\hline Spain & $55 \%$ & 4.2 & 30 & -29 \\
United Kingdom & $53 \%$ & 2.1 & 48 & 14 \\
Germany & $59 \%$ & 1.1 & 31 & 6 \\
France & $74 \%$ & 4.0 & 69 & $-6,-14,41$ \\
Italy & $83 \%$ & 4.5 & 57 & 40,20 \\
United States & $36 \%$ & 1.9 & 148 & -13 \\
Japan & $39 \%$ & 1.9 & 90 & 9 \\
\hline
\end{tabular}

Source: Own elaboration based on the Passport database of Euromonitor International is http://www.euromonitor.com/passport, last access July 2015 and on Organisation for Economic Co-operation and Development (OECD), Statistics section, http://stats.oecd.org/, last access, July 2015. 


\section{Conclusion}

We seek to explore the importance of transient industry effects in various industries, across many countries. In applying the method of Ariño et al. (2008), we are able to replicate some of the significant results found by the authors in 2008, in particular with regard to the Spanish cava and beer industries, as well as the international new passenger car sector. Further, we investigate changes in industry exposure over time, which leads us to extend the scope of our analysis to events beyond the business cycle. In the case of cava, such events include the celebrations for the new millennium, the 2005 boycott against Catalan products and the recent financial crisis. For the beer industry, the events include warm summers, excise duties and consumer optimism or pessimism. In the automotive sector, we focus on the government incentives in terms of both their direct and net effects. These exogenous shocks represent deviations from the relationship between an industry and the business cycle. Therefore, beyond the exposure of the industry to the economy, and the intensity of this exposure, such social or political events may help managers better plan production and improve decisions.

Furthermore, changing consumer habits can also be inferred from our analysis. Acknowledgment of such trends is also part of managerial decision making, especially in relation to advertising context and the launch of new products. For example, the preference for premium lager of French consumers and, to a lesser extent, U.K. consumers, is largely shaping the competitive landscape. Moreover, a solid understanding of the causes of market stagnation in the German beer market is key for beer companies in terms of competing and surviving.

From the point of view of policy makers, our analysis of the automotive industry brings to the forefront the impact of government intervention in the form of incentive schemes to countercyclically boost the sales of cars. Depending on the duration of the scheme, consumer attitudes, and other factors such as environmental considerations and rising fuel prices, the reaction to government intervention varies by country. The results are interesting for assessing the net impact of government measures, which may not always be positive in the long run. Upon close inspection of the structures of each scheme, future researchers could investigate the parameters that increase the likelihood of the net effect being positive.

Beyond country comparisons, our data enable us to make some comparisons between industries within the same country. For example, the exposures of our models developed for beer and cava in Spain are of similar strength but the intensity of each exposure differs in that it is considerably smaller for beer than for cava. Such general observations allow policy makers to infer characteristics of one industry relative to another, with respect to how intensely they will react to a change in national economic activity. Such insights may improve the effect of policy actions. For instance, in conjunction with the business cycle, tax programs may impact consumer demand for one product more than another, leading to lower sales and reduced government income from tax collections.

Our research contributes to the transient industry literature by providing new insights into the importance of transient effects. Further, the application of the transient industry effects model allows us to identify lasting changes in the relationship of the particular industry and the business cycle, as well as important external shocks, whose impact cannot be neglected, either in the production planning and strategic decisions taken by the industry or in the policy making assumed by the government. 


\section{References}

Ariño, M. A., A. Ariño, and R. Garcia-Castro (2008), “A Model to Evaluate Transient Industry Effects.” Managerial and Decision Economics, 29(8), pp. 629-637.

Cava Regulatory Board. Retrieved from http://www.crcava.es/.

Euromonitor (2014), Database. Passport.

Euromonitor (2014), Market Reports. Passport.

European Alcohol Policy Alliance. Retrieved from http://www.eurocare.org/resources/country_profiles/spain.

French, Craig W. (2003), “The Treynor Capital Asset Pricing Model.” Journal of Investment Management, 1(2), pp. 60-72.

Gujarati, D. (2007), Basic Econometrics. New Delhi: Tata McGraw-Hill. pp. 278-284.

Hamilton, L. C. (2004), Statistics with Stata. Update for version 8. Australia: Thomson-Brooks/Cole.

Hawawini, G., V. Subramanian, and P. Verdin (2003), "Is Performance Driven by Industry - or Firm-Specific Factors? A New Look at the Evidence.” Strategic Management Journal, 24, pp. 1-16.

Hurst, W., E. Gregory, and T. Gussman (1997), International Survey: Alcoholic Beverage Taxation and Control Policies, ninth edition, Ottawa: Brewers Association of Canada. McGahan, A. M., and M. E. Porter (1997), "How Much Does Industry Matter, Really?" Strategic Management Journal, 18, pp. 15-30.

McGahan, A. M., and M. E. Porter (2002), “What Do We Know About Variance in Accounting Profitability?” Management Science, 48(7), pp. 834-851.

Merton, R. C. (1973), “An Intertemporal Capital Asset Pricing Model.” Econometrica, 41(5), pp. 867-887.

National Statistics Institute (INE), Madrid. Retrieved from http://www.ine.es/.

OECD (2009), “The Automobile Industry In and Beyond the Crisis.” OECD Economic Outlook, 2009/2, No. 86, pp. 87-117.

OECD (2012), OECD Economic Outlook, 2012/1, No. 91.

Roquebert, J. A., R. L Phillips, and P. A. Westfall (1996), “Markets vs. Management: What “Drives” Profitability?” Strategic Management Journal, 17, pp. 653-664.

Rumelt, R. P. (1991), “How Much Does Industry Matter?” Strategic Management Journal, 12(3), pp. 167-185.

Schmalensee, R. (1985), “Do Markets Differ Much?” American Economic Review, 75, pp. 341-351.

Sivak, M., and B. Schoettle (2009), The Effect of the "Cash for Clunkers" Program on the Overall Fuel Economy of Purchased New Vehicles. Transportation Research Institute, University of Michigan. 